\title{
Combining radiotherapy and immunotherapy in definitive treatment of head and neck squamous cell carcinoma: review of current clinical trials
}

\author{
Gaber Plavc ${ }^{1,2}$, Primoz Strojan ${ }^{1,2}$ \\ ${ }^{1}$ Department of Radiation Oncology, Institute of Oncology Ljubljana, Ljubljana, Slovenia \\ ${ }^{2}$ Faculty of Medicine, University of Ljubljana, Ljubljana, Slovenia \\ Radiol Oncol 2020; 54(4): 394-408.; 54(4): 377-393.
}

Received 18 August 2020

Accepted 22 September 2020

Correspondence to: Assist. Gaber Plavc, M.D., Institute of Oncology Ljubljana, Department of Radiation Oncology, Zaloška cesta 2, SI-1000 Ljubljana, Slovenia. E-mail: gplavc@onko-i.si

Disclosure: No potential conflicts of interest were disclosed.

\begin{abstract}
Background. Head and neck squamous cell carcinoma (HNSCC) presents as locally advanced disease in a majority of patients and is prone to relapse despite aggressive treatment. Since immune checkpoint inhibitors (ICI) have shown clinically significant efficacy in patients with recurrent/metastatic HNSCC (R/M HNSCC), a plethora of trials are investigating their role in earlier stages of disease. At the same time, preclinical data showed the synergistic role of concurrently administered radiotherapy and ICls (immunoradiotherapy) and explained several mechanisms behind it. Therefore, this approach is prospectively tested in a neoadjuvant, definitive, or adjuvant setting in non-R/M HNSCC patients. Due to the intricate relationship between host, immunotherapy, chemotherapy, and radiotherapy, each of these approaches has its advantages and disadvantages. In this narrative review we present the biological background of immunoradiotherapy, as well as a rationale for, and possible flaws of, each treatment approach, and provide readers with a critical summary of completed and ongoing trials.

Conclusions. While immunotherapy with ICls has already become a standard part of treatment in patients with R/M HNSCC, its efficacy in a non-R/M HNSCC setting is still the subject of extensive clinical testing. Irradiation can overcome some of the cancer's immune evasive manoeuvres and can lead to a synergistic effect with ICls, with possible additional benefits of concurrent platinum-based chemotherapy. However, the efficacy of this combination is not robust and details in trial design and treatment delivery seem to be of unprecedented importance.
\end{abstract}

Key words: head and neck neoplasms; immunoradiotherapy; radiotherapy; immunotherapy

\section{Introduction}

Head and neck squamous cell carcinoma (HNSCC) accounts for more than 800,000 new cancer cases and over 400,000 deaths each year worldwide. ${ }^{1}$ Despite aggressive therapeutic approaches the outcomes are still highly dependent on disease burden. Five-year disease control ranges from almost $100 \%$ in patients with T1a glottic carcinoma to below $30 \%$ in patients with locally-advanced hypopharyngeal cancer. ${ }^{2,3}$ More than $60 \%$ of all cases are locally-advanced at diagnosis with a $50 \%$ rate of relapse in the first two years, despite the use of multimodal state-of-the-art treatment. ${ }^{4}$ Therefore, while treatment-related toxicity is now of primary concern in early stage HNSCC and low-risk human papilloma virus (HPV) mediated oropharyngeal carcinomas, with 3-year overall survival rates in excess of $90 \% 5,6$, in other patients the focus of research is on treatment intensification and/or modification.

After intrinsic tumour suppressor mechanisms fail, further tumour progression is the result of an inefficient elimination phase or equilibrium phase 
of the extrinsic tumour suppression by the immune system. ${ }^{7}$ Genetically unstable cancer cells under constant immune selection pressure evade immune recognition and destruction. Thus, they become invisible to immune cells by reducing the presentation of tumour antigens, decreasing their sensitivity to the cytotoxic effects of immune cells, and rendering their microenvironment immunosuppressive. ${ }^{7}$ In the fight against the latter, immune checkpoint inhibitors (ICI) targeting immune checkpoint programmed cell death protein 1 (anti-PD-1) are now considered standard care in recurrent and metastatic HNSCC (R/M HNSCC). ${ }^{8,9}$ Because of their proven efficacy and significantly improved toxicity profile as well as positive effect on quality of life as compared to standard chemotherapy regimens, an increasing number of trials are testing ICIs in the earlier stages of HNSCC. ${ }^{10-12}$

Besides a well-known immunosuppressive effect of radiotherapy (RT), it can also lead to positive alterations in innate and adaptive immunity. ${ }^{13}$ The same is true for the positive effects of the immune system on radiation efficacy, as a tumoricidal effect of RT is dependent on functional $\mathrm{T}$ cells, even at ablative doses. ${ }^{14}$ Furthermore, RT induces programmed death-ligand 1 (PD-L1) expression in dendritic cells (DCs) and cancer cells which contributes to acquired cancer radioresistance, which could be overcome by concurrent anti-PD-1/L1. ${ }^{15}$ These intricate interactions form the basis for combined treatment with RT and ICIs (immunoradiotherapy). This combination was shown to cause similar toxicity compared to either RT or ICI alone across different cancer types. ${ }^{16}$ Encouraging efficacy of this treatment combination has also been shown in early prospective trials in metastatic malignant melanoma and non-small cell lung cancer. ${ }^{17-21}$ The first results of trials using immunoradiotherapy in non-R/M HNSCC are now also available and many are underway. In this review we presented a biological rationale for the combination of RT and anti-PD-1/L1 and performed a systematic search for, and critical assessment of, completed and ongoing trials using a combination in non-R/M HNSCC.

\section{Role of anti-PD-1 and radiotherapy in immune rejection of HNSCC}

The efficacy of anti-PD1 therapy in HNSCC is poor with less than $20 \%$ of responding patients. ${ }^{8,22,23}$ These high rates of primary or acquired resistance in R/M HNSCC to anti-PD1 agents are a result of absent antigenic proteins, defective antigen presentation, $\mathrm{T}$ cell exhaustion/absence, insensibility of tumours to $\mathrm{T}$ cells, presence of immunosuppressive cells, and/or presence of other inhibitory immune checkpoints. ${ }^{24}$

For the immune system to exert its cytotoxic function, mutant peptides, also known as tumour neoantigens (TNA) or ectopically expressed antigens, must be presented to antigen-presenting cells by cancer cells on major histocompatibility complex I (MHC I). ${ }^{25}$ Even though the tumour mutation burden in HNSCC is rather high with 5 mutations per million base pairs, a proper presentation is needed for them to elicit an immune response. ${ }^{26,27}$ A vital role of antigen processing machinery in this step is evident by the absence of $\mathrm{CD}^{+} \mathrm{T}$ cell recognition of HNSCC in the case of defective antigen processing machinery (defect present in $20-80 \%$ of HNSCCs). ${ }^{28-30}$ The next step is presentation of the TNA by MHC I. The complete loss of MHC I results in natural killer (NK) cells' activation, while aberrant expression is beneficial for cancer cells and is present in up to $60 \%$ of HNSCCs. ${ }^{31-33} \mathrm{Up}$ to $80 \%$ of HNSCC patients overexpress the epidermal growth factor receptor (EGFR), which also downregulates MHC I. ${ }^{34}$ Treatment with anti-PD-1 was shown to be less efficient in cancers with aberrant MHC I. ${ }^{35,36}$

Yet tumour antigenicity is not enough to elicit immune response by itself. TNA presentation must be put in context by accompanying adjuvants in the form of danger-associated molecular patterns (DAMP) which are recognised by pattern recognition receptors on the cells of innate immunity. Different types of DAMPs are exposed by different modes of cell death and even by stressed cancer cells. ${ }^{37}$ These include membrane-bound calreticulin, emitted ATP, and passively released nuclear high-mobility group box protein 1 (HMGB1). This leads to the recruitment and activation of dendritic (DCs) and other mononuclear cells. ${ }^{38,39}$ DCs crosspresent antigens to naïve $\mathrm{CD} 8^{+} \mathrm{T}$ and by co-stimulatory signals (ligands and cytokines provided by DCs upon stimulation by DAMPs and type I interferons [IFNs]) prime these cytotoxic T lymphocytes in regional lymph nodes. ${ }^{40}$ Type I IFN is produced by cancer cells as a result of a stimulator of interferon genes (STING) responding to DNA in the cytosol of cancer cell, which is a consequence of cancer's unstable genome. ${ }^{41,42}$

To prevent unnecessary damage to surrounding tissue in their fight against viruses, $\mathrm{CD} 8^{+} \mathrm{T}$ lymphocytes also express inhibitory receptors, such 
as PD-1, with its ligand PD-L1 on host tissue and immune cells. ${ }^{43}$ The same PD-L1 expression is exploited by cancer cells to escape immune surveillance. ${ }^{44}$ An active PD-1/PD-L1 pathway in tumour microenvironment (TME) also promotes T cell exhaustion and differentiation of regulatory $\mathrm{T}$ cells (Treg). ${ }^{45}$ Primed tumour-infiltrating lymphocytes (TILs) that are suppressed due to PD-1/PD-L1 interaction are vital for anti-PD-1 efficacy, which also tips the balance from differentiation of exhausted $\mathrm{T}$ cells and Tregs towards generation of effector $\mathrm{T}$ cells. ${ }^{45,46}$

Immunostimulatory effect of RT depends a great deal on inducing the above-described immunogenic cell death, with dose-dependent (from 2 to $20 \mathrm{~Gy}$ ) increase in concentrations of DAMPs calreticulin, HMGB1, and ATP. ${ }^{47} \mathrm{RT}$ also produces free cytosolic DNA which is more pronounced in cancers with a loss of p53 function, as is the case in the majority of HNSCC. ${ }^{48,49}$ Cytosolic DNA is sensed by various pattern recognition receptors with STING being a central connecting protein. Activation of the cyclic GMP-AMP synthaseSTING (cGAS-STING) pathway by free cytosolic DNA leads to type I IFN production in cancer and DCs. ${ }^{41,50}$ Regarding antigenicity, RT increases MHC I expression and diversifies the tumour-infiltrating $\mathrm{T}$ cell receptor repertoire which is a positive predictor of response to anti-PD-1/L1. ${ }^{51-53}$ Previously silent mutated genes can be expressed by RT, thus leading to presentation of these TNAs by MHC $\mathrm{I}^{54,55} \mathrm{RT}$ also induces some constituents of antigen processing machinery by enhancing degradation of proteins into peptides. ${ }^{51}$ The positive effects of RT are also apparent in TME. By reducing tumour hypoxia and consequently reducing the expression of vascular endothelial growth factor, SBRT can inhibit mobilisation of myeloid-derived suppressor cells (MDSC). ${ }^{56}$ Some authors also observed an enhanced recruitment of T cells into TME after RT. ${ }^{57}$ RT-enhanced death receptor Fas expression further promotes the antitumour activity of recruited T cells. ${ }^{58,59}$ Furthermore, RT promotes the function and differentiation of cytotoxic $\mathrm{T}$ cells by inducing interleukin-1B, tumour necrosis factor- $\alpha$, and interleukin-6. ${ }^{13}$ Considering vasculature, low dose RT increases the ratio of antitumoural macrophages type 1 and tumour-promoting macrophages type 2 , which leads to vascular normalisation and T cell recruitment. ${ }^{60}$ Besides, low dose RT also appears to decrease TME's immunosuppressive cells such as Tregs and MDSCs. ${ }^{61}$ Another beneficial vasculature-related effect of RT is induction of cell adhesion molecules, for example Intercellular Adhesion
Molecule 1 and E-selectin, that help leukocytes extravasate to TME. ${ }^{62}$

Importantly, as a part of standard treatment in HNSCC, concurrent platin-based chemoradiotherapy (CRT) was also shown to induce immunogenic cell death. ${ }^{47}$ In the in vitro model, antigen presentation and $\mathrm{T}$ cell cytotoxicity were enhanced by moderate doses of cisplatin. In the in vivo mouse model synergism of cisplatin and anti-PD-1 was observed. ${ }^{63}$ However, cisplatin also resulted in PD-L1 upregulation on cancer cells and higher doses were immunosuppressive. Nevertheless, Luo et al. showed on murine cancer models that cisplatin combined with anti-PD-1 treatment enhances RTinduced abscopal effect in non-irradiated nodes. ${ }^{64}$

It should be noted that all the above-mentioned effects of RT were observed in preclinical studies and are not universally beneficial, as was shown in clinical setting. Release of DAMPs HMGB1 and ATP, which is degraded into extracellular adenosine, can have many immunosuppressive effects. ${ }^{65-70}$ Activation of cGAS-STING can lead to increased concentrations of MDSC in TME and even increase cancer aggressiveness. ${ }^{71,72}$ STING activation can also lead to depletion of tryptophan in TME via upregulation of Indoleamine 2,3-dioxygenase, resulting in reduced $\mathrm{T}$ cell cytotoxicity and increased tumour-associated macrophages and MDSCs. ${ }^{73,74}$ Even sustained type I IFN signalling is detrimental as it results in increased Treg and MDSC concentrations in TME and enhanced expression of PD-1. ${ }^{75}$ Besides, RT increases tumour growth factor beta concentration which was shown to promote tumour-promoting macrophages type 2 differentiation and inhibit DCs and cytotoxic T cells. ${ }^{13}$ In addition, RT was shown to even upregulate hypoxia inducible factor- $1 \alpha$, leading to eventual Treg and MDSC accumulation and DC and T cell inhibition via vascular endothelial growth factor. ${ }^{76-80}$

\section{Methods}

We searched PubMed and Clinicaltrials.gov databases with search terms ((immunoradiotherapy OR radioimmunotherapy) OR ((head and neck) OR (oral cavity) OR (oropharyngeal) OR (oropharynx) OR (larynx) OR (laryngeal) OR (hypopharynx) OR (hypopharyngeal)) AND (immunotherapy OR checkpoint OR pembrolizumab OR avelumab OR atezolizumab OR camrelizumab OR durvalumab OR avelumab OR nivolumab OR toripalimab OR PD-1 OR PD-L1 OR tremelimumab OR CTLA-4) 
TABLE 1. Neoadjuvant immunoradiotherapy trials

\begin{tabular}{|c|c|c|c|c|c|c|c|}
\hline Trial, start year & Phase & $\mathbf{N}$ & $\begin{array}{l}\text { Subsite and } \\
\text { subtype }\end{array}$ & Basic scheme & $\begin{array}{l}\text { Immunotherapy } \\
\text { details }\end{array}$ & RT details & Main results \\
\hline $\begin{array}{l}\text { NIRT-HNC, } \\
\text { NCTO3247712, } \\
2018\end{array}$ & 1 & 10 & $\begin{array}{l}\text { HPV+ resectable } \\
\text { HNSCC stage } \\
\text { I-III or CUP with } \\
\text { clinical indications } \\
\text { for adj. RT or TORS } \\
\text { ineligible }\end{array}$ & $\begin{array}{l}\text { NIVO+SBRT } 5 \\
\text { weeks before } \\
\text { surgery, followed } \\
\text { by NIVO }\end{array}$ & $\begin{array}{l}3 \times \text { NIVO neoadj. } \\
\text { and } 3 x \text { adj. NIVO } \\
\text { starting } 4 \text { weeks } \\
\text { postop. }\end{array}$ & $\begin{array}{l}\text { SBRT to } \\
\text { GTV+3mm; } 5 \text { pts: } \\
5 \times 8 G y \text { daily }(A) \text {, } \\
\text { and } 5 \text { pts: } 3 \times 8 G y \\
\text { (B) every other } \\
\text { day; delivered } \\
\text { between 1st and } \\
\text { 2nd NIVO cycle }\end{array}$ & $\begin{array}{l}\text { no surgical } \\
\text { delays; G3 } \\
\text { postop. toxicity } \\
\text { higher in cohort } \\
\text { A; pCR: } 100 \% \text { in } \\
\text { cohort A, and } \\
80 \% \text { in cohort B. }\end{array}$ \\
\hline $\begin{array}{l}\text { NCT03635164,91 } \\
2018\end{array}$ & I & 18 & $\begin{array}{l}\text { HPV- resectable } \\
\text { LAHNSCC }\end{array}$ & $\begin{array}{l}\text { DURVA+SBRT 3-6 } \\
\text { weeks before } \\
\text { surgery, followed } \\
\text { by DURVA }\end{array}$ & $\begin{array}{l}\text { DURVA neoadj. } \\
\text { with the first SBRT } \\
\text { fraction and up to } \\
6 \times \text { DURVA postop. }\end{array}$ & $\begin{array}{l}\text { SBRT to gross } \\
\text { disease only, } \\
\text { starting dose of } \\
2 \times 6 G y \text { (planned } \\
\text { increase to } \\
3 \times 6 G y, \text { cohort } \\
\text { size of } 3 \text { patients) } \\
\text { every other } \\
\text { day, starting } \\
\text { concurrently with } \\
\text { DURVA }\end{array}$ & NA \\
\hline $\begin{array}{l}\text { NCT03618134,92 } \\
2018\end{array}$ & $1 / 11$ & 82 & $\begin{array}{l}\text { TORS eligible } \\
\text { HPV+ } \\
\text { oropharyngeal } \\
\text { HNSCC }\end{array}$ & $\begin{array}{l}\text { DURVA+SBRT+/- } \\
\text { tremelimumab } \\
5-7 \text { weeks before } \\
\text { TORS, followed by } \\
\text { DURVA }\end{array}$ & $\begin{array}{l}\text { DURVA+/- } \\
\text { tremelimumab } \\
\text { neoadj. with the } \\
\text { first SBRT fraction } \\
\text { and on day } 27 \text {, } \\
\text { followed by up to } \\
4 x \text { adj. DURVA }\end{array}$ & $\begin{array}{l}\text { SBRT in 5fx, } \\
\text { starting } \\
\text { concurrently } \\
\text { with DURVA+/- } \\
\text { tremelimumab }\end{array}$ & NA \\
\hline
\end{tabular}

adj. = adjuvant; CUP = cancer of unknown primary; DURVA = durvalumab; $f x=$ fraction; $G T V=$ gross tumour volume; G3 = grade $3 ;$ HNSCC = head and neck squamous cell carcinoma; HPV- = human papilloma virus negative cancer; HPV+ = human papilloma virus associated cancer; LAHNSCC = locally advanced HNSCC; $\mathrm{N}=$ planned number of enrolled patients, $\mathrm{NA}=$ not available; neoadj. = neoadjuvantly, NIVO = nivolumab; $\mathrm{pCR}=$ pathological complete response; postop. = postoperatively; pts = patients; $\mathrm{RT}$ = radiotherapy, $\mathrm{SBRT}=$ stereotactic body $\mathrm{RT}$; TORS = transoral robotic surgery

AND (radiotherapy OR SBRT OR RT OR SABR OR irradiation) and with the start date of the studies from $15^{\text {th }}$ July 2013 to $15^{\text {th }}$ July 2020 . In total, 39 completed or ongoing trials were found, using concurrent (chemo)radiotherapy and ICIs in primary definitive treatment of non-R/M HNSCC (non-nasopharyngeal).

\section{Trials using anti-PD-1/L1 and radiotherapy combination in HNSCC: different approaches}

In completed and ongoing trials, concurrent antiPD-1/L1 and RT was delivered either before or after surgery, or as a sole definitive treatment. Few delivered anti-PD-1/L1 also as an extended consolidative treatment. Taking the intricate relationship between the immune system and therapy into account, attention to the below-described caveats should help shed light on the pros and cons of these research approaches.

\section{Neoadjuvant immunoradiotherapy}

Except for the earliest stages of HNSCC, elective neck treatment either by lymphadenectomy or irradiation is part of the standard treatment. ${ }^{81}$ Lymph nodes are also one of the places where DCs cross-prime CD8 ${ }^{+} \mathrm{T}$ lymphocytes. ${ }^{82}$ Even though the immediate treatment effect of concurrent antiPD-1 and RT depends primarily on TILs already present in the primary tumour, T cells from lymph nodes are responsible for long-lasting tumour control. ${ }^{83,84}$ Preclinical studies in murine cancer models clearly showed the vital role of functioning draining lymph nodes for RT efficacy with or without concurrent ICI. 85,86 Removal of draining lymph nodes or elective nodal irradiation led to reduced tumour-specific TILs. ${ }^{85,86}$ Furthermore, clinical data show reduced efficacy of anti-PD-1 in previously treated patients with HNSCC. ${ }^{87}$ This speaks strongly in favour of using an immunoradiotherapy combination before surgery as compared to its postoperative application. 
Neoadjuvant RT is not considered a standard of care in HNSCC, therefore these "window of opportunity trials" serve mostly to advance our understanding of the underlying mechanisms and to lay the ground for further studies. ${ }^{88}$ Special attention must be therefore given to patient safety. In the, so far only, immunoradiotherapy "window of opportunity" trial that reported results, no surgical delays were noted. ${ }^{89}$ The possibility of anti-PD-1 induced hyperprogression must nevertheless be kept in mind as it was reported in up to $29 \%$ of patients with R/M HNSCC. ${ }^{90}$

The ongoing trials are presented in detail in Table 1. Leidner et al. completed phase I of their phase I/II trial and already provided intriguing results. ${ }^{89}$ In the first phase, 10 patients with stage I-III HPV associated HNSCC or cancer of unknown primary with clinical indications for adjuvant RT or who were ineligible for transoral robotic surgery were accrued. Two cohorts were formed of which five patients received neoadjuvant SBRT with $5 \times 8$ Gy (A cohort), and another five patients had SBRT with 3x8 Gy (B cohort), both with concurrent nivolumab. No grade 4 toxicity was observed, with somewhat higher grade 3 toxicity in the A cohort. Notably, grade 2 renal insufficiency was observed in $50 \%$ of patients. Both fractionation regimens were shown to be effective with $100 \%$ and $80 \%$ complete pathological responses in the A and B cohort, respectively. However, on presurgical imaging evaluated by RECIST criteria, no complete responses were found. Recently, preliminary results of their phase II cohort expansion were also presented. ${ }^{91}$ Only the SBRT fractionation of the B cohort was further pursued. In cohort $C$ inclusion criteria were the same as in cohorts A and B, while these six patients were treated with only neoadjuvant SBRT, followed by surgery and adjuvant nivolumab. Cohort $\mathrm{D}$ included only patients with HPV-negative HNSCC, and these five patients were treated the same as those in cohort B (SBRT with $3 \times 8$ Gy concurrently with nivolumab). Results were so far only vaguely described: there was no limiting toxicity, but the complete pathological response rate was somewhat lower than in cohorts A and B. In-detail results are awaited.

The approach to treatment was similar in HPVnegative HNSCC patients in the NCT03635164 trial, with the difference that anti-PD-L1 agent durvalumab was used instead of nivolumab. ${ }^{91}$ The third ongoing trial (NCT03618134) with a similar approach is testing whether the addition of tremelimumab, an anti-cytotoxic T-lymphocyteassociated protein 4 (anti-CTLA-4), to durvalumab can improve the outcome in HPV-positive HNSCC patients. ${ }^{92}$ These two ICIs provide complementary effects, albeit at the expense of increased toxicity. 93,94

\section{Definitive immunoradiotherapy}

Considering only non-cancer/TME-related factors, synergism between anti-PD-1 and RT is probably most pronounced when these two treatment modalities are delivered concurrently in previously untreated patients with intact draining lymph nodes and no lymphopenia. ${ }^{85-87,95-98}$ Definitive immunoradiotherapy as a sole treatment fulfils these criteria, except for nodal irradiation. If, in a neoadjuvant setting, elective nodal irradiation is not mandatory, its omission would be ill-advised in a definitive (chemo)radiotherapy setting based on our current knowledge. ${ }^{81}$ However, advancement in diagnostic imaging and treatment (e.g. sentinel lymph node biopsy) provides the basis for ongoing trials testing reduced dose and/or volume of elective nodal irradiation which would be welcomed in immunoradiotherapy as well. ${ }^{99}$

Preclinical studies also provide rather strong support for greater efficacy of hypofractionated RT compared to conventionally fractionated RT. ${ }^{56,100,101}$ In contrast to all the above-listed trials with immunotherapy in the neoadjuvant setting, however, the definitive setting immunoradiotherapy trials mostly utilise conventionally fractionated RT courses as compared to hypofractionated SBRT. This could be an important outcome-defining factor.

Concurrent chemoradiotherapy with cisplatin causes severe radiomucositis (grade 3-4) in around $40 \%$ of HNSCC patients. ${ }^{102,103}$ Even though antiPD-1/L1 induced oral mucositis or stomatitis occurs in less than $3 \%$ of patients and is usually mild, it can nevertheless occasionally be severe. ${ }^{104}$ Special attention should be paid to this when using an approach with combined CRT and anti-PD-1/L1, despite the fact that pertinent trials have so far not reported exacerbated toxicity in oral mucosa (see below). Another important aspect of concurrent CRT and immunotherapy is the effect of chemotherapy on immunotherapy's efficacy which seems to be beneficial in low doses, whereas high-dose chemotherapy is known to cause myelosuppression and could be detrimental to the efficacy of immunotherapy. ${ }^{63,64}$ Several trials use ICI combined with cetuximab, an anti- EGFR agent. Cetuximab is a mouse/human chimeric monoclonal IgG1 antibody. ${ }^{105}$ Besides acting through targeting EGFR and dysregulating its signaling pathway, it also stimulates NK cells anti- 
tumour activity, activates DCs, and recruits cytotoxic $\mathrm{CD} 8{ }^{+} \mathrm{T}$ cells. ${ }^{105}$ Cetuximab's ability to prime adaptive and innate immunity is met with regulatory immunosuppressive mechanisms. Targeting these immunosuppressive mechanisms (induction of Tregs, MDSC, PD-1, PD-L1, CTLA-4) by immunotherapy such as ICI has great potential and is still being tested in several trials. ${ }^{106} \mathrm{~A}$ prospective trial using anti-PD-1 combined with cetuximab in 33 patients with platinum-refractory/ineligible R/M HNSCC showed a $41 \%$ response rate. About a third of patients experienced treatment-related grade 3 toxicity. ${ }^{107}$ Furthermore, retrospectively gathered data on a triple combination of cetuximab, chemotherapy and anti-PD-1 used in 15 patients with R/M HNSCC was presented in 2018 by Lin et al. ${ }^{108}$ The combination seemed effective with $58 \%$ partial responses and acceptable toxicity.

Completed and ongoing trials treating patients with non-R/M HNSCC with a definitive immunoradiotherapy combination are presented in Table 2, while important details are presented below.

JAVELIN Head and Neck 100 (NCT02952586) is the first randomised phase III trial combining CRT with concomitant ICI in patients with LAHNSCC to be terminated due to inefficiency. ${ }^{109}$ Concurrent administration of a PD-L1 inhibitor avelumab and standard CRT (70 Gy and high-dose cisplatin) followed by maintenance avelumab for 12 months was compared to a placebo arm receiving the same CRT but with placebo instead of avelumab in 697 high-risk LAHNSCC patients. ${ }^{110}$ A pre-planned interim analysis showed that this combination is unlikely to show a significant improvement in progression-free survival and the trial was therefore terminated. Detailed study findings are awaited.

In a GORTEC 2017-01 REACH trial (NCT02999087), two standard arms (CRT with a three-weekly high-dose cisplatin in a cohort of patients fit for high-dose cisplatin, and RT with concurrent cetuximab in a cohort of patients unfit for high-dose cisplatin) were compared to experimental arms with the same RT regimen and concurrent avelumab and cetuximab (preliminary results, Table 2). ${ }^{111,112}$ All patients completed RT except for one cisplatin-ineligible patient receiving RT concurrently with avelumab and cetuximab. $88 \%$ and $76 \%$ of patients received all planned doses of avelumab and cetuximab, respectively. A grade $\geq 4$ adverse effect occurred in 5/41 (12\%) patients in experimental arms (all in the cohort of patients ineligible for high-dose cisplatin), and in 5/41 (12\%) patients in standard arms (14\% in high-dose cisplatin eligible and $10 \%$ in high-dose cisplatin ineli- gible patients) where one grade 5 toxicity was also observed. The trial continues.

In 2019, results of the lead-in phase of randomised phase II/III trial NRG-HN004 (NCT03258554) were presented. Ten out of a planned 523 cisplatin-ineligible patients received durvalumab concomitantly with RT and all completed RT as planned, while $8 / 10$ patients received all the planned durvalumab cycles. Randomisation will continue to either RT with durvalumab or RT with cetuximab. ${ }^{113}$

The GORTEC 2015-01 PembroRad randomised phase II trial's safety-related results were presented in 2018. ${ }^{114}$ In 133 cisplatin ineligible patients with LAHNSCC cetuximab or pembrolizumab were added to conventional RT, which resulted in a similar completion rate of RT ( 86 vs. $88 \%$ ) and dysphagia (34 vs. $39 \%$ ). However, mucositis was more prevalent in the cetuximab arm and the same goes for dermatitis (49 vs. 17\%) (Table 2). Final results are still awaited.

The results of the first 16 randomised patients of the planned 120 patients with HPV- LAHNSCC in a DURTRE-RAD trial (NCT03624231) were recently presented. ${ }^{115}$ Among the first six patients treated with a combination of RT, durvalumab and tremelimumab (arm A), five patients (83\%) stopped treatment due to immune-related adverse effects (irAE), of which one was grade 5 . This arm was terminated due to excessive toxicity. Arm B with only durvalumab added to $\mathrm{RT}$, which resulted in only $1 / 10$ patients stopping treatment due to irAE, is continuing to enrol.

Weiss et al. (NCT02609503) presented the results of their phase II trial after a median follow-up of 21 months. ${ }^{116}$ In 29 cisplatin ineligible patients with LAHNSCC pembrolizumab was given concurrently with definitive RT and for an additional three adjuvant cycles (Table 2). The estimated two-year overall and progression-free survival was $75 \%$ and $71 \%$ respectively. RT was delivered in full in 28/29 patients, and 25/29 patients received all pembrolizumab doses. Toxicities were mild with a major exception being grade 3-4 lymphopenia, which occurred in $59 \%$ of patients, however, absolute lymphopenia did not predict for progression. Further characterisation of this unexpected lymphopenia showed declines in blood concentrations of B cells and $\mathrm{CD} 4^{+} \mathrm{T}$ cells, whereas $\mathrm{CD} 8^{+} \mathrm{T}$ cells were relatively preserved..$^{116}$

Powel et al. presented results from their phase I trial (NCT02586207), testing pembrolizumab with chemoradiotherapy in 59 patients with LAHNSCC. ${ }^{117}$ Pembrolizumab was discontinued due to irAE in 9\% during CRT and for non-irAE 
TABLE 2. Definitive immunoradiotherapy trials

\begin{tabular}{|c|c|c|c|c|c|c|c|}
\hline Trial, start year & Phase & $\mathbf{N}$ & $\begin{array}{l}\text { Subsite and } \\
\text { subtype }\end{array}$ & Basic scheme & $\begin{array}{l}\text { Immunotherapy } \\
\text { details }\end{array}$ & RT details & Main results \\
\hline $\begin{array}{l}\text { NCT02586207, } 117 \\
2015\end{array}$ & 1 & 59 & $\begin{array}{l}\text { LAHNSCC } \\
\text { eligible for CRT } \\
\text { (34 pts HPV } \\
+ \text { and } 23 \text { pts } \\
\text { HPV-) }\end{array}$ & $\begin{array}{l}\text { PEMBRO + CRT, } \\
\text { followed by PEMBRO }\end{array}$ & $\begin{array}{l}\text { PEMBRO on days } \\
-7 \text { (before CRT), } \\
15 \text { and } 36 \text { (conc. } \\
\text { with CRT), and } \\
\text { adj. for } 5 \text { cycles }\end{array}$ & $\begin{array}{l}\text { starting on day 1: } \\
\text { CRT with IMRT } 70 \\
\text { Gy }(2 \mathrm{~Gy} / \mathrm{fx}) \text { and } \\
\text { LD-CDDP for } 6 \\
\text { cycles }\end{array}$ & $\begin{array}{l}\text { HPV + : 85\% CR } 12 \\
\text { weeks after CRT; } \\
\text { HPV-: } 78 \% \text { CR } 12 \\
\text { weeks after CRT; } \\
\text { HPV + : 2-year OS } \\
97 \% \text { and PFS } 93 \% ; \\
\text { HPV-: 1-year OS } \\
87 \% \text { and PFS } 73 \%\end{array}$ \\
\hline $\begin{array}{l}\text { GORTEC 2015-01 } \\
\text { "PembroRad" } \\
\text { (NCT02707588), } 114 \\
2016\end{array}$ & II, rand. & 133 & $\begin{array}{l}\text { LAHNSCC } \\
\text { ineligible for } \\
\text { CDDP }\end{array}$ & $\begin{array}{l}\operatorname{arm} A: \text { CETUX + RT; } \\
\text { arm B: PEMBRO + RT }\end{array}$ & $\begin{array}{l}\text { arm A: CETUX } \\
\text { during RT; arm B: } \\
\text { PEMBRO during RT }\end{array}$ & $\begin{array}{l}\text { IMRT } \\
(69.99 \mathrm{~Gy} / 33 \mathrm{fx})\end{array}$ & $\begin{array}{l}\text { arm A: } 94 \% \text { grade } \\
3 \text { toxicity, } 57 \% \\
\text { grade } 3 \text { mucositis, } \\
86 \% \text { received full } \\
\text { RT; arm B: } 78 \% \\
\text { grade } 3 \text { toxicity, } \\
24 \% \text { grade } 3 \\
\text { mucositis, } 88 \% \\
\text { received full RT }\end{array}$ \\
\hline $\begin{array}{l}\text { KEYNOTE-412 } \\
\text { (NCT03040999), } 124 \\
2017\end{array}$ & III, rand. & 780 & $\begin{array}{l}\text { LAHNSCC } \\
\text { eligible for CRT }\end{array}$ & $\begin{array}{l}\text { arm A: PEMBRO + } \\
\text { CRT, followed by } \\
\text { PEMBRO; arm B: } \\
\text { placebo + CRT, } \\
\text { followed by placebo }\end{array}$ & $\begin{array}{l}\text { arm A: priming } \\
\text { dose of PEMBRO } \\
\text { followed by } 2 x \\
\text { PEMBRO + CRT, } \\
\text { followed by } 14 x \\
\text { maint. PEMBRO; } \\
\text { arm B: placebo } \\
\text { instead of } \\
\text { PEMBRO }\end{array}$ & $\begin{array}{l}\text { CRT (70Gy/35fx) } \\
\text { and HD-CDDP }\end{array}$ & NA \\
\hline $\begin{array}{l}\text { NCTO2759575, }{ }^{131} \\
2016\end{array}$ & $I / I I$ & 47 & $\begin{array}{l}\text { LAHNSCC of } \\
\text { larynx }\end{array}$ & PEMBRO + CRT & $\begin{array}{l}\text { PEMBRO starting } \\
3 \text { weeks before } \\
\text { CRT, maximum } 4 x\end{array}$ & $\begin{array}{l}\text { CRT (70Gy/35fx) } \\
\text { and HD-CDDP }\end{array}$ & NA \\
\hline $\begin{array}{l}\text { NCT02609503, } 116 \\
2016\end{array}$ & $\|$ & 29 & $\begin{array}{l}\text { LAHNSCC } \\
\text { ineligible for } \\
\text { CDDP }\end{array}$ & $\begin{array}{l}\text { PEMBRO + RT, } \\
\text { followed by PEMBRO }\end{array}$ & $\begin{array}{l}\text { PEMBRO conc. } \\
\text { with RT and } 3 \text { adj. } \\
\text { cycles }\end{array}$ & IMRT (70Gy/35fx) & $\begin{array}{l}\text { 2-year OS 75\% } \\
\text { and PFS 71\%; } \\
59 \% \text { grade 3-4 } \\
\text { lymphopenia }\end{array}$ \\
\hline $\begin{array}{l}\text { NCTO2777385, } 130 \\
2016\end{array}$ & II, rand. & 90 & LAHNSCC & $\begin{array}{l}\text { arm A: PEMBRO + } \\
\text { CRT; arm B: CRT } \\
\text { followed by PEMBRO }\end{array}$ & $\begin{array}{l}\text { arm A: } 8 x \\
\text { PEMBRO } 1 \text { week } \\
\text { prior to RT; arm } \\
\text { B: } 8 x \text { PEMBRO } \\
\text { beginning in } \\
\text { week } 10\end{array}$ & $\begin{array}{l}\text { CRT with IMRT } \\
\text { (70Gy/35fx) and } \\
\text { LD-CDDP }\end{array}$ & NA \\
\hline $\begin{array}{l}\text { NCT03532737, }{ }^{132} \\
2018\end{array}$ & $\|$ & 50 & LAHNSCC & $\begin{array}{l}\text { PEMBRO + CRT or } \\
\text { PEMBRO + CETUX } \\
+ \text { RT }\end{array}$ & $\begin{array}{l}\text { PEMBRO starting } \\
3 \text { weeks before } \\
\text { (C)RT and during } \\
\text { CRT or during RT + } \\
\text { CETUX }\end{array}$ & $\begin{array}{l}\text { CRT with IMRT } \\
\text { (66-70Gy/30-35fx) } \\
\text { and HD-CDDP or } \\
\text { conc. CETUX }\end{array}$ & NA \\
\hline $\begin{array}{l}\text { KEYCHAIN } \\
\text { (NCTO3383094), } 133 \\
2018\end{array}$ & II, rand. & 114 & $\begin{array}{l}\text { HPV + } \\
\text { LAHNSCC }\end{array}$ & $\begin{array}{l}\text { arm A: PEMBRO + RT; } \\
\text { arm B: CRT }\end{array}$ & $\begin{array}{l}\text { arm A: conc. and } \\
\text { adj. PEMBRO for } \\
20 \text { cycles; arm B: } \\
\text { CDDP-based CRT }\end{array}$ & $\begin{array}{l}\text { IMRT (70Gy/33- } \\
35 f x)(\text { arm A) and } \\
\text { HD-CDDP in arm B }\end{array}$ & NA \\
\hline $\begin{array}{l}\text { PEACH } \\
\text { (NCT02819752), } 134 \\
2017\end{array}$ & 1 & 36 & LAHNSCC & $\begin{array}{l}\text { PEMBRO + CRT, } \\
\text { followed by PEMBRO }\end{array}$ & $\begin{array}{l}\text { pre-loading dose } \\
\text { of PEMBRO (dose- } \\
\text { escalation trial, } \\
100-200 \mathrm{mg} \text { ) and } \\
\text { conc. CRT and } \\
\text { PEMBRO and } 4 \mathrm{x} \\
\text { adj. PEMBRO }\end{array}$ & standard CRT & NA \\
\hline $\begin{array}{l}\text { NCTO4369937, } 127 \\
2020\end{array}$ & $\|$ & 50 & $\begin{array}{l}\text { IR HPV + } \\
\text { HNSCC }\end{array}$ & $\begin{array}{l}\text { HPV-16 vaccination } \\
\text { (ISA101b) + } \\
\text { PEMBRO + CRT }\end{array}$ & $\begin{array}{l}\text { 3x ISA } 101 \mathrm{~b} \\
\text { starting } 1 \text { week } \\
\text { prior to PEMBRO } \\
\text { and two weeks } \\
\text { prior to CRT }\end{array}$ & $\begin{array}{l}\text { CRT with IMRT } \\
\text { (70Gy/35fx) and } \\
\text { HD-CDDP }\end{array}$ & NA \\
\hline $\begin{array}{l}\text { RTOG } 3504 \\
\text { (NCT02764593), } 120 \\
2016\end{array}$ & 1 & 40 & $\begin{array}{l}\text { IR-HR } \\
\text { LAHNSCC }\end{array}$ & $\begin{array}{l}\text { conc. and adj. NIVO } \\
\text { added to each of } 4 \\
\text { (C)RT cohorts }\end{array}$ & $\begin{array}{l}\text { conc. NIVO } \\
\text { starting } 2 \text { weeks } \\
\text { before (C)RT and } \\
\text { adj. NIVO starting } \\
3 \text { months after } \\
\text { CRT }\end{array}$ & $\begin{array}{l}\text { all cohorts: IMRT } \\
\text { (70Gy/35fx); } \\
\text { cohort 1: CRT with } \\
\text { LD-CDDP; cohort } \\
\text { 2: CRT with HD- } \\
\text { CDDP; cohort 3: } \\
\text { RT + CETUX; cohort } \\
4: \text { RT }\end{array}$ & $\begin{array}{l}\text { adj. NIVO } \\
\text { infeasible after } \\
\text { HD-CDDP or in } \\
\text { CDDP-ineligible } \\
\text { pts; low rates of } \\
\text { NIVO DLT }\end{array}$ \\
\hline $\begin{array}{l}\text { NCTO3349710, } 125 \\
2017\end{array}$ & III, rand. & 1046 & LAHNSCC & $\begin{array}{l}\text { NIVO + RT vS. CETUX } \\
+ \text { RT vs. NIVO + CRT } \\
\text { vs. CRT }\end{array}$ & \multicolumn{3}{|c|}{ Closed due to slow accrual } \\
\hline
\end{tabular}




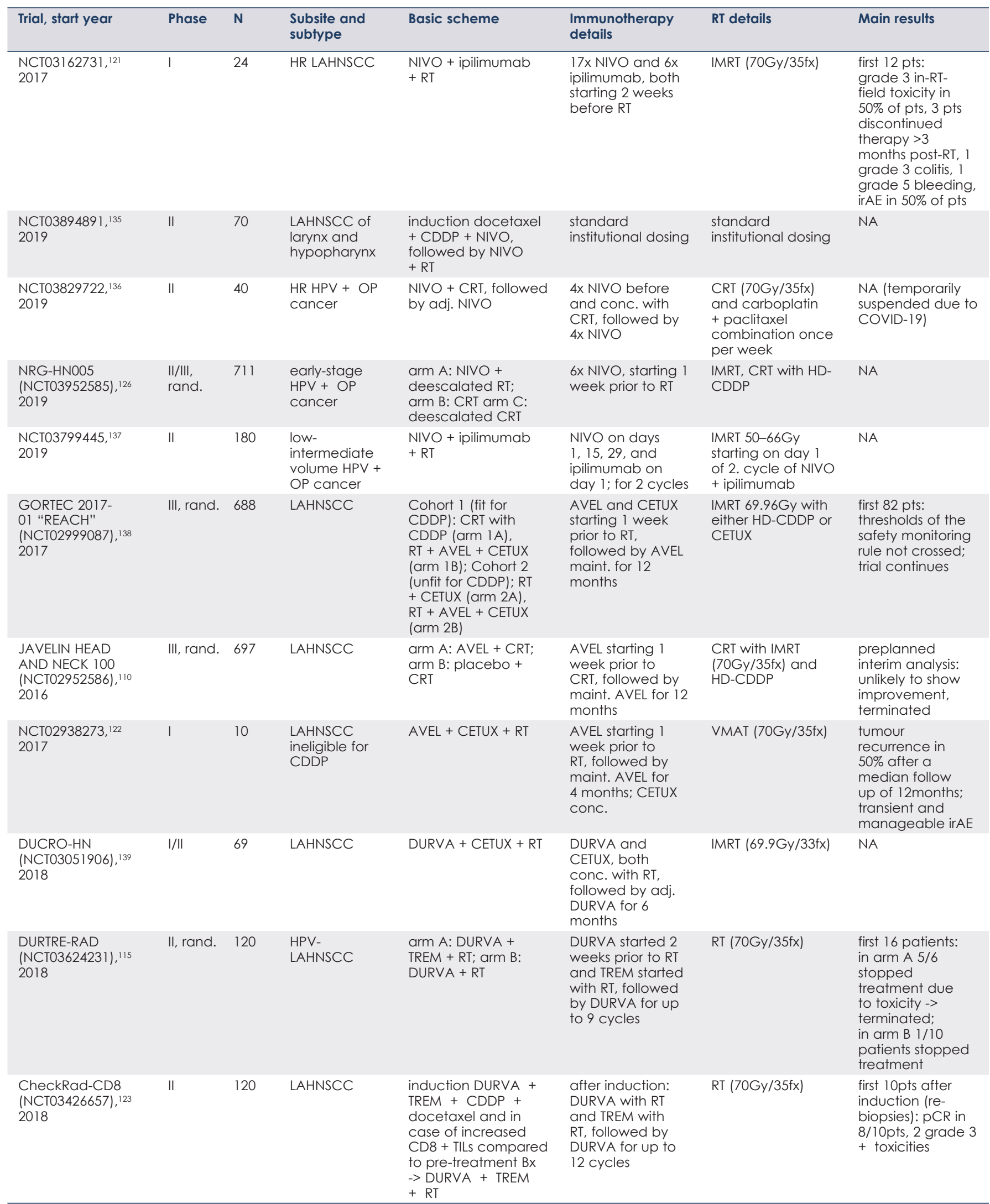




\begin{tabular}{|c|c|c|c|c|c|c|c|}
\hline Trial, start year & Phase & $\mathbf{N}$ & $\begin{array}{l}\text { Subsite and } \\
\text { subtype }\end{array}$ & Basic scheme & $\begin{array}{l}\text { Immunotherapy } \\
\text { details }\end{array}$ & RT details & Main results \\
\hline $\begin{array}{l}\text { NRG-HNO04 } \\
\text { (NCTO3258554), } 113 \\
2017\end{array}$ & $\begin{array}{l}\text { II/III, } \\
\text { rand. }\end{array}$ & 523 & $\begin{array}{l}\text { LAHNSCC } \\
\text { ineligible for } \\
\text { CDDP }\end{array}$ & $\begin{array}{l}\text { arm A: DURVA + RT; } \\
\text { arm B: CETUX + RT }\end{array}$ & $\begin{array}{l}\text { DURVA started } \\
2 \text { weeks prior to } \\
\text { RT for } 7 \text { cycles; } \\
\text { CETUX conc. }\end{array}$ & RT (70Gy/35fx) & $\begin{array}{l}\text { lead-in trial, } 10 \\
\text { pts: all received } \\
\text { arm A treatment, } \\
\text { all completed RT, } \\
8 / 10 \text { received all } \\
\text { doses of DURVA }\end{array}$ \\
\hline $\begin{array}{l}\text { CITHARE } \\
\text { (NCT03623646), }{ }^{140} \\
2019\end{array}$ & II, rand. & 66 & $\begin{array}{l}\text { early-stage } \\
\mathrm{HPV}+\mathrm{OP} \\
\text { cancer }\end{array}$ & $\begin{array}{l}\operatorname{arm} \text { A: DURVA + RT; } \\
\text { arm B: CRT }\end{array}$ & $\begin{array}{l}\text { DURVA conc. } \\
\text { with RT }\end{array}$ & $\begin{array}{l}\text { RT 70Gy with CDDP } \\
\text { in arm B }\end{array}$ & NA \\
\hline $\begin{array}{l}\text { REWRITe } \\
\text { (NCTO3726775), }{ }^{129} \\
2018\end{array}$ & ॥ & 73 & $\begin{array}{l}\text { HNSCC T1-2 } \\
\text { or HNSCC } \\
\text { T3-4 and not } \\
\text { eligible for } \\
\text { CRT/CETUX } \\
+ \text { RT }\end{array}$ & $\begin{array}{l}\text { DURVA + RT, } \\
\text { followed by } \\
\text { additional } 6 \text { months } \\
\text { of DURVA }\end{array}$ & $\begin{array}{l}\text { DURVA conc. with } \\
\text { RT, followed by } 6 \\
\text { months of DURVA }\end{array}$ & $\begin{array}{l}\text { RT to only primary } \\
\text { tumour and } \\
\text { immediately } \\
\text { adjacent nodal } \\
\text { level without } \\
\text { extended neck } \\
\text { irradiation }\end{array}$ & NA \\
\hline $\begin{array}{l}\text { NCT04405154, }{ }^{141} \\
2020\end{array}$ & ॥ & 32 & LAHNSCC & CRT + camrelizumab & $\begin{array}{l}\text { camrelizumab } \\
\text { conc. with CRT } \\
\text { and after for total } \\
\text { of } 8 \text { cycles }\end{array}$ & $\begin{array}{l}\text { CRT with } \\
\text { IMRT/VMAT } \\
\text { (66-70Gy/33-35fx) } \\
\text { and HD-CDDP }\end{array}$ & NA \\
\hline
\end{tabular}

adj. = adjuvantly; $\mathrm{AVEL}=$ avelumab; CETUX = cetuximab; $;$ CDDP = cisplatin; conc. = concurrently; $C R=$ complete response; $C R T=$ chemoradiotherapy; DLT = dose-limiting toxicity; DURVA = durvalumab; , fx = fractions; HD-CDDP = high dose cisplatin $100 \mathrm{mg} / \mathrm{m}^{2}$ every three weeks during RT; HR = high-risk; HPV+ = human papilloma virus associated cancer, HPV- = human papilloma virus negative cancer; IMRT = intensity modulated RT; IR = intermediate-risk; irAE - immune-related adverse effects; LAHNSCC = locally advanced head and neck squamous cell carcinoma; LD-CDDP = low dose cisplatin $40 \mathrm{mg} / \mathrm{m}^{2}$ every week during RT; maint. = maintenance; $\mathrm{N}=$ planned enrolment; $\mathrm{NA}=$ not available; NIVO = nivolumab; OP = oropharyngeal; OS = overall survival; PEMBRO = pembrolizumab; PFS = progression-free survival; RT = radiotherapy, TILs = tumour infiltrating lymphocytes; TREM - tremelimumab; VMAT = volumetric modulated arc therapy

related causes in $12 \%$ after CRT. The goal cisplatin dose of $200 \mathrm{mg} / \mathrm{m}^{2}$ or more was received by $88 \%$ of patients and $98 \%$ of patients received all $70 \mathrm{~Gy}$ of RT. $76 \%$ of patients received all eight planned pembrolizumab cycles. Grade 4 toxicities were solely hematologic and electrolyte abnormalities. Outcomes are described in Table 2.

In the RTOG 3504, a phase I trial enrolling 40 patients with intermediate risk (HPV-associated oropharyngeal HNSCC, T1-2N2b-N3/T3-4N0-3, >10 pack-years or $\mathrm{T} 4 \mathrm{~N} 0-\mathrm{N} 3, \mathrm{~T} 1-3 \mathrm{~N} 3 \leq 10$ pack-years) or high-risk LAHNSCC (oral cavity, laryngeal, hypopharyngeal, or HPV-negative oropharyngeal HNSCC, T1-2N2a-N3 or T3-4N0-3), nivolumab was added to each of four (C)RT cohorts in a concurrent and adjuvant setting. ${ }^{118-120}$ RT was delivered with either a weekly low-dose or three-weekly highdose cisplatin, with cetuximab, or as monotherapy (Table 2). The addition of nivolumab concurrently to all four (C)RT regimens was found safe. Levels of dose-limiting toxicity were acceptable and after 17, 16, 10, and 6 months of median follow-up in each of the four RT cohorts there were 0/10 (RT plus weekly cisplatin), 1/9 (RT plus three-weekly cisplatin), 1/10 (RT plus cetuximab), and 3/10 (RT only) events (i.e. death or disease progression), respectively. However, adjuvant administration of nivolumab was infeasible after (C)RT in cisplatinineligible patients or in those who received highdose three-weekly concurrent cisplatin.
Data from the first 12 patients (planning to enrol 24 patients) from the NCT03162731 phase I trial, adding nivolumab and ipilimumab to standard RT in high-risk LAHNSCC, were also presented. ${ }^{121}$ After a follow-up of 7.2-18.4 months, 10 of the 12 patients are alive with no evidence of disease. Major toxicities are presented in Table 2.

Elbers et al. recently reported results from their phase I trial (NCT02938273) in 10 cisplatin ineligible patients with LAHNSCC that received avelum$\mathrm{ab}$ and cetuximab in conjunction with RT, followed by avelumab as a maintenance therapy for an additional four months (Table 2). ${ }^{122}$ After a median follow-up of 12 months disease recurred in $50 \%$ of the patients. The majority of adverse effects were related to RT and cetuximab; grade 3 irAE occurred in four patients and were successfully managed.

An innovative approach is used in the CheckRad-CD8 phase II trial (NCT03426657) in which 120 patients with LAHNSCC have a second biopsy after induction durvalumab, tremelimum$a b$, cisplatin, and docetaxel therapy. In the case of increased $\mathrm{CD} 8^{+}$TILs compared to pre-treatment biopsy, patients receive concurrent durvalumab, tremelimumab, and RT. Non-responders continue with standard therapy outside of the trial. The interim analysis for the first 10 patients was presented in 2019. After induction therapy re-biopsies showed a complete pathological response in $8 / 10$ patients with another two patients showing an in- 
crease in $\mathrm{CD}^{+}$TILs. There were two cases of grade III-IV toxicity: hepatitis and infectious diarrhoea. ${ }^{123}$ Further results are awaited.

There are an additional 16 ongoing trials employing a combination of RT and ICIs that have not presented their results yet. Two of these are randomized phase III studies. The first one, KEYNOTE-412, will hopefully provide robust data to clarify the role of anti-PD-1 agent pembrolizumab given concomitantly with CRT and as a maintenance therapy in patients with locally advanced HNSCC. ${ }^{124}$ The interpretation of the results could be hindered by the inability to discern the distinct effects of the priming, concurrent, and maintenance applications of pembrolizumab. Notably, a similar international phase III trial has previously been terminated due to slow accrual, and another similar trial, JAVELIN Head and Neck 100, testing the addition of anti-PD-L1 agent to CRT in LAHNSCC was terminated due to inefficiency. ${ }^{109,125}$ An additional phase III trial, NRG-HN005, is a non-inferiority trial, testing treatment de-escalation in patients with early stage HPV-positive oropharyngeal carcinoma. ${ }^{126}$ A reduced dose RT, concurrently with either cisplatin or nivolumab, will be compared to standard CRT with cisplatin. The results will add valuable information to expanding pool of knowledge from the de-escalation trials in patients with HPV-positive HNSCC.

A somewhat different approach will be examined in the NCT04369937. ${ }^{127} \mathrm{HPV}-16$ E6/E7-specific therapeutic vaccination (ISA101b) will be administered to 50 patients with intermediate risk of HPV+ HNSCC one week prior to the start of pembrolizumab and two weeks prior to the start of CRT with cisplatin (Table 2). The combination of ISA101 and nivolumab was already examined in a singlearm phase II trial where 24 patients with incurable HPV-positive cancers (22 oropharyngeal and one cervical and one anal cancer) were enrolled. An overall response rate of $33 \%$ with a median duration of response of 10.3 months and a median overall survival of 17.5 months seemed promising. ${ }^{128}$

REWRITe (NCT03726775), a phase II trial that started in 2018, follows the recommendations from preclinical studies about omitting extended elective nodal irradiation when combining RT with immunotherapy. In this trial, patients with early stage T1-2 HNSCC or those with T3-4 disease and who are ineligible for cisplatin or cetuximab concurrently with RT will simultaneously receive durvalum$\mathrm{ab}$ and RT to the primary tumour and immediately adjacent lymph nodes only. This will be followed by six months of maintenance durvalumab. ${ }^{129}$
NCT02777385 is a phase II trial, planning to randomise 90 patients with LAHNSCC to either concurrent CRT with cisplatin and pembrolizumab or to CRT followed by pembrolizumab (Table 2). ${ }^{130}$ It will hopefully help to answer if concurrent application is better than sequential or vice versa.

\section{Adjuvant (postoperative) immunoradiotherapy}

Testing novel treatments in an adjuvant setting offers a unique opportunity to stratify operated patients by risk of recurrence based on a detailed histopathological report, and therefore to avoid overtreatment. However, one should be aware of the above-described disadvantages when using immunotherapy with or without concurrent radiotherapy in patients with resected draining lymph nodes or after intensive treatment.

Two trials testing the potentials of adjuvant immunoradiotherapy reported early results. WiseDraper et al. presented results of the lead-in stage of their phase II trial (NCT02641093). One to three weeks before planned surgery, patients who were clinically at high risk (cT3/4 stage and/or $\geq 2+\mathrm{LNs}$ ) had one priming application of pembrolizumab followed by risk adjusted administration of adjuvant pembrolizumab in combination with RT or CRT. The pathological response to priming application of pembrolizumab was seen in $47 \%$ and was correlated with increased TILs. Adjuvant combination treatment with pembrolizumab and RT/CRT has an acceptable safety profile (Table 3). ${ }^{142}$ The other trial is a phase I NRG-HN003 trial that was conducted with the aim of determining a schedule for a phase II study. The tested regimen consisted of pembrolizumab added to adjuvant RT in patients with previously resected HPV-negative HNSCC with microscopically positive margins or an extracapsular extension of nodal metastases. ${ }^{143}$ Pembrolizumab administered every three weeks in a dose of $200 \mathrm{mg}$ for eight doses, starting the week before adjuvant CRT, was declared as worth pursuing. irAE were rare and non-significant (Table 3).

Beside these, there are six more ongoing trials registered in the international databases delivering different concurrent immunoradiotherapy combinations in an adjuvant setting and three of them are randomised phase 3 trials. The experimental arm in KEYNOTE-689 (NCT03765918) is similar to the one in trial by Wise-Draper et al., except that two cycles of neoadjuvant pembrolizumab will be administered and longer maintenance therapy with pembrolizumab is planned. This will be com- 
TABLE 3. Trials utilizing adjuvant immunoradiotherapy

\begin{tabular}{|c|c|c|c|c|c|c|c|}
\hline Trial, start year & Phase & $\mathbf{N}$ & $\begin{array}{l}\text { Subsite and } \\
\text { subtype }\end{array}$ & Basic scheme & $\begin{array}{l}\text { Immunotherapy } \\
\text { details }\end{array}$ & RT details & Main results \\
\hline NCT02641093, ${ }^{142} 2016$ & $\|$ & 80 & LAHNSCC & $\begin{array}{l}\text { neoadj. PEMBRO } \\
\text { followed by } \\
\text { resection, } \\
\text { followed by } \\
\text { PEMBRO + (C)RT }\end{array}$ & $\begin{array}{l}\text { PEMBRO } 1 \text { week } \\
\text { prior to surgery } \\
\text { and conc. with } \\
\text { RT for total of } 7 \\
\text { doses }\end{array}$ & $\begin{array}{l}\text { IMRT } \\
\text { (60-66Gy/30fx) + } \\
\text { /- LD-CDDP (if ECE } \\
+/ R 1)\end{array}$ & $\begin{array}{l}\text { first } 23 \text { pts (lead- } \\
\text { in phase): } 47 \% \\
\text { pathological } \\
\text { response, no DLT, } \\
2 \text { pts recurred }\end{array}$ \\
\hline $\begin{array}{l}\text { NRG-HNO03 } \\
\text { (NCTO2775812), } 143 \\
2016\end{array}$ & 1 & 34 & $\begin{array}{l}\text { resected RI/ECE } \\
+\mathrm{HPV}-\mathrm{HNSCC}\end{array}$ & $\begin{array}{l}\text { adj. PEMBRO + } \\
\text { CRT }\end{array}$ & $\begin{array}{l}3 \text { different } \\
\text { schedules aimed } \\
\text { to determine } \\
\text { phase II schedule }\end{array}$ & $\begin{array}{l}\text { CRT with IMRT } \\
\text { (60Gy/30fx) and } \\
\text { LD-CDDP }\end{array}$ & $\begin{array}{l}\text { No irAE } \\
\text { unacceptably } \\
\text { delayed RT, } 50 \% \\
\text { got all } 8 \text { doses of } \\
\text { PEMBRO }\end{array}$ \\
\hline $\begin{array}{l}\text { KEYNOTE-689 } \\
\text { (NCTO3765918), 144,145 } \\
2018\end{array}$ & III, rand. & 600 & $\begin{array}{l}\text { resected } \\
\text { LAHNSCC }\end{array}$ & $\begin{array}{l}\text { arm A: neoadj. } \\
\text { PEMBRO followed } \\
\text { by resection then } \\
\text { PEMBRO + (C)RT; } \\
\text { arm B: resection } \\
\text { then (C)RT }\end{array}$ & $\begin{array}{l}\text { arm A: } 2 x \text { neoadj. } \\
\text { PEMBRO and } \\
\text { PEMBRO conc. } \\
\text { with adj. (C) } \\
\text { RT, followed by } \\
\text { PEMBRO for up to } \\
15 \text { cycles }\end{array}$ & $\begin{array}{l}\text { (C)RT } \\
60-70 G y / 30-35 f x \\
+/-H D-C D D P \\
\text { depending on risk } \\
\text { factors }\end{array}$ & NA \\
\hline $\begin{array}{l}\text { GORTEC 2018-01 } \\
\text { "NIVOPOSTOP" } \\
\text { (NCTO3576417), } 146 \\
2018\end{array}$ & III, rand. & 680 & $\begin{array}{l}\text { resected R1/ECE } \\
+ \text { LAHNSCC }\end{array}$ & $\begin{array}{l}\text { arm A: adj. NIVO } \\
\text { + CRT; arm B: adj. } \\
\text { CRT }\end{array}$ & $\begin{array}{l}\text { NIVO starting } 3 \\
\text { weeks before } \\
\text { CRT for total of } 4 \\
\text { doses }\end{array}$ & $\begin{array}{l}\text { CRT with IMRT } \\
\text { (66Gy/33fx) and } \\
\text { HD-CDDP }\end{array}$ & NA \\
\hline $\begin{array}{l}\text { ADHERE } \\
\text { (NCT03673735), }, 147 \\
2019\end{array}$ & III, rand. & 650 & $\begin{array}{l}\text { resected HR HPV- } \\
\text { HNSCC }\end{array}$ & $\begin{array}{l}\operatorname{arm} A: \text { adj. } \\
\text { DURVA + CRT; } \\
\text { arm B: adj. CRT }\end{array}$ & $\begin{array}{l}1 \text { dose of DURVA } \\
1 \text { week prior to } \\
\text { CRT and maint. } \\
\text { DURVA for } 6 \\
\text { doses }\end{array}$ & $\begin{array}{l}\text { CRT 66Gy/33fx } \\
\text { and HD-CDDP }\end{array}$ & NA \\
\hline $\begin{array}{l}\text { ADRISK } \\
\text { (NCT03480672), }{ }^{149} \\
2018\end{array}$ & II, rand. & 240 & $\begin{array}{l}\text { resected } \\
\text { LAHNSCC with } \\
>1 \text { LN/ECE + /R I }\end{array}$ & $\begin{array}{l}\text { arm A: adj. } \\
\text { PEMBRO + CRT; } \\
\text { arm B: adj. CRT }\end{array}$ & $\begin{array}{l}\text { PEMBRO conc. } \\
\text { with RT and for up } \\
\text { to } 12 \text { months }\end{array}$ & CRT with CDDP & NA \\
\hline NCT03715946, ${ }^{150} 2018$ & $\|$ & 135 & $\begin{array}{l}\text { resected IR- } \\
\text { HR HPV + } \\
\text { oropharyngeal } \\
\text { cancer }\end{array}$ & $\begin{array}{l}\text { adj. NIVO + } \\
\text { deescalated RT }\end{array}$ & $\begin{array}{l}\text { NIVO conc. } \\
\text { with RT and for } \\
\text { additional } 6 \text { doses } \\
\text { after RT }\end{array}$ & RT (45-50Gy/25fx) & NA \\
\hline NCT03529422,151 2019 & $\|$ & 33 & $\begin{array}{l}\text { resected IR } \\
\text { HNSCC }\end{array}$ & adj. DURVA + RT & $\begin{array}{l}\text { DURVA starting } \\
\text { conc. with RT for } \\
\text { total of } 6 \text { cycles }\end{array}$ & IMRT (60Gy/30fx) & NA \\
\hline
\end{tabular}

adj. = adjuvant; $\mathrm{CDDP}=$ cisplatin; conc. $=$ concurrent; $\mathrm{CRT}=$ chemoradiotherapy; $\mathrm{DLT}=$ dose-limiting toxicity; DURVA = durvalumab; $\mathrm{ECE}+=$ extracapsular extension of metastasis in lymph node; $\mathrm{fx}=$ fractions; HD-CDDP = high dose cisplatin $100 \mathrm{mg} / \mathrm{m}^{2}$ every three weeks during RT; HPV+ = human papilloma virus associated cancer; HPV- = human papilloma virus negative cancer: $H R=$ high-risk; IMRT = intensity modulated RT: IR = intermediate-risk; irAE = immune-related adverse effects: $L A H N S C C=$ locally advanced head and neck squamous cell carcinoma; $\mathrm{LD}$-CDDP = low dose cisplatin $40 \mathrm{mg} / \mathrm{m}^{2}$ every week during RT; $\mathrm{N}=$ planned enrolment; neoadj. = neoadjuvant; $\mathrm{NIVO}=$ nivolumab; $\mathrm{PEMBRO}=$ pembrolizumab; $\mathrm{RT}=$ radiotherapy; $\mathrm{R} 1$ = microscopically positive resection margin, $\mathrm{LN}=$ lymph node; $\mathrm{NA}=$ not available

pared to standard adjuvant CRT in LAHNSCC patients with either more than one pathological lymph node, microscopically positive margins or an extracapsular extension of nodal metastases. ${ }^{144,145}$ The two other randomised phase III trials, GORTEC 2018-01 (NCT03576417, also known as NIVOPOSTOP) ${ }^{146}$ and ADHERE (NCT03673735) ${ }^{147}$, will both enrol patients with resected high-risk HNSCC and randomise them to either adjuvant CRT with concurrent nivolumab (NIVOPOSTOP)/ durvalumab (ADHERE), or to standard of care adjuvant CRT. These three phase III trials could set ground for the new era in the setting of adjuvant treatment of a high-risk HNSCC based on pathological data (microscopically positive margins or extracapsular extension of nodal metastases). Currently, with adjuvant CRT locoregional relapse rates as well as distant metastases rates at five years are around $20 \%$ in these patients. ${ }^{102,148}$ Based on the preclinical data described above, it would be reasonable to expect a synergistic locoregional activity of radioimmunotherapy. A major drawback of adding immunotherapeutics to RT in postoperative setting could be the absence of regional lymph nodes that could hinder the efficacy of this combination. Nevertheless, ICIs will be delivered in doses that were shown to be effective systemically, therefore, it is justified to expect improved distant control of the disease..$^{8,10}$

The other three phase I and phase II trials are presented in Table 3.

\section{Adjuvant/maintenance therapy with immune checkpoint inhibitor}

In several of the above-described trials anti-PD-1/ L1 therapy is also applied as a prolonged adjuvant or maintenance therapy. Support for this approach 
comes from two other tumour types. In patients with unresectable locally-advanced non-squamous cell carcinoma lung cancer (NSCLC) without progression after definitive CRT, consolidation durvalumab was shown to prolong survival. ${ }^{152}$ Also, after a complete resection of stage III melanoma, adjuvant ipilimumab prolonged overall survival compared to placebo, while adjuvant nivolumab compared head-to-head to adjuvant ipilimumab showed better relapse-free survival and less toxicity. Long-term data of the latter study are not yet available. ${ }^{153,154}$ Besides differences in tumour-intrinsic factors and the composition of their TME, another important aspect to consider is the different recurrence pattern of these tumours. While melanoma and NSCLC are prone to dissemination, HNSCC tends to recur more often locoregionally in previously treated tissue. After resection alone, stage III melanoma spreads to distant sites in more than $60 \%$ of cases, and stage III NSCLC relapses distantly after CRT alone in up to $50 \%$ of cases. ${ }^{154,155}$ On the other hand, the risk of distant metastases is around $15 \%$ in HNSCC, whereas isolated locoregional relapses are much more common. ${ }^{4,156}$ Whether consolidation anti-PD-1/L1 agents can decrease rates of distant metastases as well as locoregional relapses in HNSCC is still to be determined.

Another important consideration in prolonged treatment with anti-PD-1/L1 agents is toxicity. Even though the overall effect on the quality of life with anti-PD-1 agents in R/M HNSCC was found to be positive and there were fewer adverse effects compared to standard chemotherapy, irAE nevertheless occurred in around $60 \%$ of patients with $17 \%$ of them experiencing a grade 3 or higher toxic event. ${ }^{22,157}$ Prolonged treatment with anti-PD-1/L1 agents should therefore be approached carefully and weighted against its toxicity. It should not be ignored that there is also financial toxicity associated with these treatments. It was estimated that in CheckMate 141 the incremental cost-effectiveness ratio per quality-adjusted life year for nivolumab was around 90,000 euros. ${ }^{158}$ Even if the methods used in such calculations had some flaws, the financial burden of these new drugs is obvious and therefore special attention should already be paid in trial design. ${ }^{158}$ Importantly, with the above-described trials it will be hard to discern the benefit of concurrent immunoradiotherapy from the benefit of maintenance immunotherapy as none of these trials compares this extended adjuvant treatment to a comparator arm without it. In either case, careful patient selection for immunotherapy, probably biomarker driven, will help to prevent unneces- sary additional toxicity and the financial burden of this treatment. Potential biomarkers for immunotherapy in HNSCC have recently been extensively reviewed by Gavrielatou et al. ${ }^{159}$

\section{Conclusions}

Researchers pursue different strategies in using a RT-ICI combination in a non-R/M HNSCC setting and the first results are already available. Window of opportunity trials are most welcomed since biological mechanisms behind the synergistic effect of combined immunoradiotherapy are not fully understood and reliable criteria for patient selection are lacking. The first results of these trials that use immunoradiotherapy neoadjuvantly are encouraging. In a definitive setting results are more varied. A large phase III trial employing concurrent and maintenance avelumab for 12 months post-chemoradiotherapy was terminated because of inefficacy. Prolonged RT courses with large treatment fields and high doses of concomitant chemotherapy agents could be detrimental to the success of immunotherapy. In an adjuvant setting it is hard to overlook factors such as a changed anatomy of lymphatics and a changed microenvironment of possible remaining cancer cells due to previous surgery, which could both adversely affect the effectiveness of immunoradiotherapy. Additionally, many of these trials administer anti-PD-1/L1 agents not only concurrently with RT but also as prolonged adjuvant treatment, without a comparator arm for proper evaluation of this approach. However, immunoradiotherapy is evolving rapidly in HNSCC and final results of the herein presented ongoing trials are eagerly awaited.

\section{Acknowledgments}

This study was funded by the Slovenian Research Agency (program no. P3-0307).

\section{References}

1. Bray F, Ferlay J, Soerjomataram I, Siegel RL, Torre LA, Jemal A. Global cancer statistics 2018: GLOBOCAN estimates of incidence and mortality worldwide for 36 cancers in 185 countries. CA Cancer J Clin 2018; 68: 394-424. doi: $10.3322 /$ caac. 21492

2. Petersen JF, Timmermans AJ, van Dijk BAC, Overbeek LIH, Smit LA, Hilgers FJM, et al. Trends in treatment, incidence and survival of hypopharynx cancer: a 20-year population-based study in the Netherlands. Eur Arch OtoRhino-Laryngology 2018; 275: 181-9. doi: 10.1007/s00405-017-4766-6 
3. Goor KM, Peeters AJGE, Mahieu HF, Langendijk JA, Leemans CR, Verdonckde Leeuw IM, et al. Cordectomy by CO2 laser or radiotherapy for small T1a glottic carcinomas: Costs, local control, survival, quality of life, and voice quality. Head Neck 2007; 29: 128-36. doi: 10.1002/hed.20500

4. Argiris A, Karamouzis MV, Raben D, Ferris RL. Head and neck cancer. Lancet 2008; 371: 1695-709. doi: 10.1016/S0140-6736(08)60728-X

5. Corry J, Smee R, Ferlito A, Suárez C, Rapidis AD, Strojan P, et al. Management of locally advanced HPV-related oropharyngeal squamous cell carcinoma: where are we? Eur Arch Oto-Rhino-Laryngology 2015; 273: 2877-94. doi: 10.1007/s00405-015-3771-x

6. Ang KK, Harris J, Wheeler R, Weber R, Rosenthal DI, Nguyen-Tân PF, et al. Human papillomavirus and survival of patients with oropharyngeal cancer. N Engl J Med 2010; 363: 24-35. doi: 10.1056/NEJMoa0912217

7. Schreiber RD, Old $\amalg$, Smyth MJ. Cancer immunoediting: integrating immunity's roles in cancer suppression and promotion. Science 2011; 331: 1565-70. doi: 10.1126/science. 1203486

8. Burtness B, Harrington KJ, Greil R, Soulières D, Tahara M, de Castro G, et al. Pembrolizumab alone or with chemotherapy versus cetuximab with chemotherapy for recurrent or metastatic squamous cell carcinoma of the head and neck (KEYNOTE-048): a randomised, open-label, phase 3 study. Lancet 2019; 394: 1915-28. doi: 10.1016/S0140-6736(19)32591-7

9. Ferris RL, Blumenschein G, Fayette J, Guigay J, Colevas AD, Licitra L, et al. Nivolumab for recurrent squamous-cell carcinoma of the head and neck. N Engl J Med 2016; 375: 1856-67. doi: 10.1056/NEJMoa1602252

10. Saba NF, Blumenschein G, Guigay J, Licitra L, Fayette J, Harrington KJ, et al. Nivolumab versus investigator's choice in patients with recurrent or metastatic squamous cell carcinoma of the head and neck: efficacy and safety in CheckMate 141 by age. Oral Oncol 2019; 96: 7-14. doi: 10.1016/j. oraloncology.2019.06.017

11. Hanna GJ, Adkins DR, Zolkind P, Uppaluri R. Rationale for neoadjuvant immunotherapy in head and neck squamous cell carcinoma. Oral Oncol 2017; 73: 65-9. doi: 10.1016/j.oraloncology.2017.08.008

12. Harrington KJ, Ferris RL, Blumenschein G, Colevas AD, Fayette J, Licitra L, et al. Nivolumab versus standard, single-agent therapy of investigator's choice in recurrent or metastatic squamous cell carcinoma of the head and neck (CheckMate 141): health-related quality-of-life results from a randomised, phase 3 trial. Lancet Oncol 2017; 18: 1104-15. doi: 10.1016/ S1470-2045(17)30421-7

13. Monjazeb AM, Schalper KA, Villarroel-Espindola F, Nguyen A, Shiao SL, Young K. Effects of radiation on the tumor microenvironment. Semin Radiat Oncol 2020; 30: 145-57. doi: 10.1016/j.semradonc.2019.12.004

14. Lee $Y$, Auh SL, Wang $Y$, Burnette B, Wang $Y$, Meng $Y$, et al. Therapeutic effects of ablative radiation on local tumor require $\mathrm{CD} 8+\mathrm{T}$ cells: changing strategies for cancer treatment. Blood 2009; 114: 589-95. doi: 10.1182/ blood-2009-02-206870

15. Deng L, Liang H, Burnette B, Beckett M, Darga T, Weichselbaum RR, et al. Irradiation and anti-PD-L1 treatment synergistically promote antitumor immunity in mice. J Clin Invest 2014; 124: 687-95. doi: 10.1172/JCI67313

16. Sha CM, Lehrer EJ, Hwang C, Trifiletti DM, Mackley HB, Drabick JJ, et al. Toxicity in combination immune checkpoint inhibitor and radiation therapy: a systematic review and meta-analysis. Radiother Oncol 2020; 151: 141-8.; doi: 10.1016/j.radonc.2020.07.035

17. Hiniker SM, Reddy SA, Maecker HT, Subrahmanyam PB, Rosenberg-Hasson $\mathrm{Y}$, Swetter SM, et al. A prospective clinical trial combining radiation therapy with systemic immunotherapy in metastatic melanoma. Int J Radiat Oncol 2016; 96: 578-88. doi: 10.1016/j.jijrobp.2016.07.005

18. Sundahl N, De Wolf K, Kruse V, Meireson A, Reynders D, Goetghebeur E, et al. Phase 1 dose escalation trial of ipilimumab and stereotactic body radiation therapy in metastatic melanoma. Int J Radiat Oncol 2018; 100: 906-15. doi: 10.1016/j.jijrobp.2017.11.029

19. Campbell AM, Cai WL, Burkhardt D, Gettinger SN, Goldberg SB, Amodio M, et al. Final results of a phase II prospective trial evaluating the combination of stereotactic body radiotherapy (SBRT) with concurrent pembrolizumab in patients with metastatic non-small cell lung cancer (NSCLC). Int J Radiat Oncol 2019; 105: S36-7. doi: 10.1016/j.jijrobp.2019.06.453
20. Theelen WSME, Peulen HMU, Lalezari F, van der Noort V, de Vries JF, Aerts JGJ V., et al. Effect of pembrolizumab after stereotactic body radiotherapy vs pembrolizumab alone on tumor response in patients with advanced non-small cell lung cancer. JAMA Oncol 2019; 5: 1276. doi: 10.1001/ jamaoncol.2019.1478

21. Patel JD, Bestvina CM, Karrison T, Jelinek MJ, Juloori A, Pointer $K$, et al. Randomized phase I trial to evaluate Concurrent or Sequential Ipilimumab, Nivolumab, and stereotactic body Radiotherapy in patients with stage IV non-small cell lung cancer (COSINR Study). [abstract]. J Clin Oncol 2020; 38(15 Suppl): 9616. doi: 10.1200/JCO.2020.38.15_suppl.9616

22. Ferris RL, Licitra L, Fayette J, Even C, Blumenschein G, Harrington KJ, et al. Nivolumab in patients with recurrent or metastatic squamous cell carcinoma of the head and neck: efficacy and safety in CheckMate 141 by prior cetuximab use. Clin Cancer Res 2019; 25: 5221-30. doi: 10.1158/10780432.CCR-18-3944

23. Cohen EEW, Soulières D, Le Tourneau C, Dinis JJ, Licitra L, Ahn MJ, et al. Pembrolizumab versus methotrexate, docetaxel, or cetuximab for recurrent or metastatic head-and-neck squamous cell carcinoma (KEYNOTE-040): a randomised, open-label, phase 3 study. Lancet 2019; 393: 156-67. doi: 10.1016/S0140-6736(18)31999-8

24. Sharma P, Hu-Lieskovan S, Wargo JA, Ribas A. Primary, adaptive, and acquired resistance to cancer immunotherapy. Cell 2017; 168: 707-23. doi: 10.1016/j.cell.2017.01.017

25. Jensen PE. Recent advances in antigen processing and presentation. Nat Immunol 2007; 8: 1041-8. doi: 10.1038/ni1516

26. Chalmers ZR, Connelly CF, Fabrizio D, Gay L, Ali SM, Ennis R, et al. Analysis of 100,000 human cancer genomes reveals the landscape of tumor mutational burden. Genome Med 2017; 9: 34. doi: 10.1186/s13073-017-0424-2

27. Schumacher TN, Schreiber RD. Neoantigens in cancer immunotherapy. Science 2015; 348: 69-74. doi: 10.1126/science.aaa4971

28. López-Albaitero A, Nayak J V., Ogino T, Machandia A, Gooding W, DeLeo $A B$, et al. Role of antigen-processing machinery in the in vitro resistance of squamous cell carcinoma of the head and neck cells to recognition by CTL. J Immunol 2006; 176: 3402-9. doi: 10.4049/jimmunol.176.6.3402

29. Meissner M, Reichert TE, Kunkel M, Gooding W, Whiteside TL, Ferrone S, et al. Defects in the human leukocyte antigen class I antigen-processing machinery in head and neck squamous cell carcinoma: association with clinical outcome. Clin Cancer Res 2005; 11: 2552-60. doi: 10.1158/10780432.CCR-04-2146

30. Concha-Benavente F, Srivastava R, Ferrone S, Ferris RL. Immunological and clinical significance of HLA class I antigen processing machinery component defects in malignant cells. Oral Oncol 2016; 58: 52-8. doi: 10.1016/j.oraloncology.2016.05.008

31. Hoglund P, Sundback J, Olsson-Alheim MY, Johansson M, Salcedo M, Ohien $\mathrm{C}$, et al. Host MHC class I gene control of NK-cell specificity in the mouse. Immunol Rev 1997; 155: 11-28. doi: 10.1111/j.1600-065X.1997.tb00936.x

32. Grandis JR, Falkner DM, Melhem MF, Gooding WE, Drenning SD, Morel PA Human leukocyte antigen class I allelic and haplotype loss in squamous cell carcinoma of the head and neck: clinical and immunogenetic consequences. Clin Cancer Res 2000; 6: 2794-802. PMID: 10914726

33. Ferris RL, Hunt JL, Ferrone S. Human leukocyte antigen (HLA) class I defects in head and neck cancer: molecular mechanisms and clinical significance. Immunol Res 2005; 33: 113-34. doi: 10.1385/IR:33:2:113

34. Pollack BP, Sapkota B, Cartee T V. Epidermal growth factor receptor inhibition augments the expression of MHC class I and II genes. Clin Cancer Res 2011; 17: 4400-13. doi: 10.1158/1078-0432.CCR-10-3283

35. Chowell D, Morris LGT, Grigg CM, Weber JK, Samstein RM, Makarov V, et al. Patient HLA class I genotype influences cancer response to checkpoint blockade immunotherapy. Science 2018; 359: 582-7. doi: 10.1126/science. aao4572

36. Chen P-L, Roh W, Reuben A, Cooper ZA, Spencer CN, Prieto PA, et al. Analysis of immune signatures in longitudinal tumor samples yields insight into biomarkers of response and mechanisms of resistance to immune checkpoint blockade. Cancer Discov 2016; 6: 827-37. doi: 10.1158/21598290.CD-15-1545

37. Patel SA, Minn AJ. Combination cancer therapy with immune checkpoint blockade: mechanisms and strategies. Immunity 2018; 48: 417-33. doi: 10.1016/j.immuni.2018.03.007 
38. Zitvogel L, Kepp O, Kroemer G. Decoding cell death signals in inflammation and immunity. Cell 2010; 140: 798-804. doi: 10.1016/j.cell.2010.02.015

39. Kroemer G, Galluzzi L, Kepp O, Zitvogel L. Immunogenic cell death in cancer therapy. Annu Rev Immunol 2013; 31: 51-72. doi: 10.1146/annurevimmunol-032712-100008

40. Sánchez-Paulete AR, Teijeira A, Cueto FJ, Garasa S, Pérez-Gracia JL, Sánchez-Arráez $A$, et al. Antigen cross-presentation and T-cell crosspriming in cancer immunology and immunotherapy. Ann Oncol 2017; 28: xii44-55. doi: 10.1093/annonc/mdx237

41. Zitvogel L, Galluzzi L, Kepp O, Smyth MJ, Kroemer G. Type I interferons in anticancer immunity. Nat Rev Immunol 2015; 15: 405-14. doi: 10.1038/ nri3845

42. Hatch EM, Fischer AH, Deerinck TJ, Hetzer MW. Catastrophic nuclear envelope collapse in cancer cell micronuclei. Cell 2013; 154: 47-60. doi: 10.1016/j.cell.2013.06.007

43. Duan S, Thomas PG. Balancing immune protection and immune pathology by CD8+ T-cell responses to influenza infection. Front Immunol 2016; 7 doi: 10.3389/fimmu.2016.00025

44. Freeman GJ, Long AJ, Iwai $\mathrm{Y}$, Bourque $\mathrm{K}$, Chernova $\mathrm{T}$, Nishimura $\mathrm{H}$, et al. Engagement of the PD-1 mmunoinhibitory receptor by a novel B7 family member leads to negative regulation of lymphocyte activation. J Exp Med 2000; 192: 1027-34. doi: 10.1084/jem.192.7.1027

45. Bardhan K, Anagnostou T, Boussiotis VA. The PD1:PD-L1/2 pathway from discovery to clinical implementation. Front Immunol 2016; 7: 550. doi: 10.3389/fimmu.2016.00550

46. Tumeh PC, Harview CL, Yearley JH, Shintaku IP, Taylor EJM, Robert L, et al. PD-1 blockade induces responses by inhibiting adaptive immune resistance. Nature 2014; 515: 568-71. doi: 10.1038/nature13954

47. Golden EB, Frances D, Pellicciotta I, Demaria S, Helen Barcellos-Hoff M, Formenti SC, et al. Radiation fosters dose-dependent and chemotherapyinduced immunogenic cell death. Oncoimmunology 2014; 3: e28518. doi: 10.4161/onci.28518

48. Lawrence MS, Sougnez C, Lichtenstein L, Cibulskis K, Lander E, Gabrie $\mathrm{SB}$, et al. Comprehensive genomic characterization of head and neck squamous cell carcinomas. Nature 2015; 517: 576-82. doi: 10.1038/nature14129

49. Durante M, Formenti SC. Radiation-induced chromosomal aberrations and immunotherapy: micronuclei, cytosolic DNA, and interferon-production pathway. Front Oncol 2018; 8: 192. doi: 10.3389/fonc.2018.00192

50. Vanpouille-Box C, Demaria S, Formenti SC, Galluzzi L. Cytosolic DNA Sensing in organismal tumor control. Cancer Cell 2018; 34: 361-78. doi: 10.1016/j.ccell.2018.05.013

51. Reits EA, Hodge JW, Herberts CA, Groothuis TA, Chakraborty M, K.Wansley $E$ et al. Radiation modulates the peptide repertoire, enhances $M H C$ class I expression, and induces successful antitumor immunotherapy. J Exp Med 2006; 203: 1259-71. doi: 10.1084/jem.20052494

52. Twyman-Saint Victor C, Rech AJ, Maity A, Rengan R, Pauken KE, Stelekat $\mathrm{E}$, et al. Radiation and dual checkpoint blockade activate non-redundant immune mechanisms in cancer. Nature 2015; 520: 373-7. doi: 10.1038/ nature14292

53. Han J, Duan J, Bai $H$, Wang $Y$, Wan $R$, Wang $X$, et al. TCR repertoire diversity of peripheral PD- $1+C D 8+T$ cells predicts clinical outcomes after immunotherapy in patients with non-small cell lung cancer. Cancer Immunol Res 2020; 8: 146-54. doi: 10.1158/2326-6066.CIR-19-0398

54. Khan S, de Giuli R, Schmidtke G, Bruns M, Buchmeier M, van den Broek M et al. Cutting edge: neosynthesis is required for the presentation of a T cell epitope from a long-lived viral protein. J Immunol 2001; 167: 4801-4. doi: 10.4049/jimmunol.167.9.4801

55. Weichselbaum RR, Hallahan D, Fuks Z, Kufe D. Radiation induction of immediate early genes: Effectors of the radiation-stress response. Int J Radiat Oncol 1994; 30: 229-34. doi: 10.1016/0360-3016(94)90539-8

56. Lan J, Li R, Yin LM, Deng L, Gui J, Chen BQ, et al. Targeting myeloid-derived suppressor cells and programmed death ligand 1 confers therapeutic advantage of ablative hypofractionated radiation therapy compared with conventional fractionated radiation therapy. Int J Radiat Oncol Biol Phys 2018; 101: 74-87. doi: 10.1016/j.jijobp.2018.01.071
57. Matsumura S, Wang B, Kawashima N, Braunstein S, Badura M, Cameron TO, et al. Radiation-induced CXCL16 release by breast cancer cells attracts effector T cells. J Immunol 2008; 181: 3099-107. doi: 10.4049/jimmunol.181.5.3099

58. Chakraborty M, Abrams SI, Camphausen K, Liu K, Scott T, Coleman CN, et al. Irradiation of tumor cells up-regulates Fas and enhances CTL Iytic activity and CTL adoptive immunotherapy. J Immunol 2003; 170: 6338-47. doi: 10.4049/jimmunol.170.12.6338

59. Chakraborty M, Abrams SI, Coleman CN, Camphausen K, Schlom J, Hodge JW. External beam radiation of tumors alters phenotype of tumor cells to render them susceptible to vaccine-mediated T-cell killing. Cancer Res 2004; 64: 4328-37. doi: 10.1158/0008-5472.CAN-04-0073

60. Klug F, Prakash H, Huber PE, Seibel T, Bender N, Halama N, et al. Low-dose irradiation programs macrophage differentiation to an iNOS+/M1 phenotype that orchestrates effective T cell immunotherapy. Cancer Cell 2013; 24: 589-602. doi: 10.1016/j.ccr.2013.09.014

61. Savage T, Pandey S, Guha C. Postablation modulation after single high-dose radiation therapy improves tumor control via enhanced immunomodulation. Clin Cancer Res 2020; 26: 910-21. doi: 10.1158/1078-0432.CCR-183518

62. Hallahan D, Kuchibhotla J, Wyble C. Cell adhesion molecules mediate radiation-induced leukocyte adhesion to the vascular endothelium. Cancer Res 1996; 56: 5150-5. PMID: 8912850

63. Tran L, Allen CT, Xiao R, Moore E, Davis R, Park SJ, et al. Cisplatin alters antitumor immunity and synergizes with PD-1/PD-L1 inhibition in head and neck squamous cell carcinoma. Cancer Immunol Res 2017; 5: 1141-51. doi: 10.1158/2326-6066.CIR-17-0235

64. Luo R, Firat E, Gaedicke S, Guffart E, Watanabe T, Niedermann G. Cisplatin facilitates radiation-induced abscopal effects in conjunction with PD-1 checkpoint blockade through CXCR3/CXCL10-mediated T-cell recruitment. Clin Cancer Res 2019; 25: 7243-55. doi: 10.1158/1078-0432.CCR-19-1344

65. Teijeira Á, Garasa S, Gato M, Alfaro C, Migueliz I, Cirella A, et al. CXCR1 and CXCR2 Chemokine receptor agonists produced by tumors induce neutrophil extracellular traps that interfere with immune cytotoxicity. Immunity 2020; 52: 856-71.e8. doi: 10.1016/j.immuni.2020.03.001

66. Shinde-Jadhav S, Mansure JJ, Rayes R, Ayoub M, Spicer J, Kassouf W. Abstract 3743: Neutrophil extracellular traps and their implication with radioresistance in muscle invasive bladder cancer. [abstract]. In: Proceedings AACR Annual Meeting 2019; March 29-April 3, 2019; Atlanta, GA. Cancer Res 2019; 79(13 Suppl): 3743. doi: 10.1158/1538-7445.AM2019-3743

67. Deaglio S, Robson SC. Ectonucleotidases as regulators of purinergic signaling in thrombosis, inflammation, and immunity. Adv Pharmacol; 2011; 61 301-32. doi: 10.1016/B978-0-12-385526-8.00010-2

68. Ohta A, Kini R, Ohta A, Subramanian M, Madasu M, Sitkovsky M. The development and immunosuppressive functions of CD4+ CD25+ FoxP3+ regulatory $T$ cells are under influence of the adenosine-A2A adenosine receptor pathway. Front Immunol 2012; 3: 190. doi: 10.3389/fimmu.2012.00190

69. Palmer TM, Trevethick MA. Suppression of inflammatory and immune responses by the $\mathrm{A} 2 \mathrm{~A}$ adenosine receptor: an introduction. Br J Pharmacol 2008; 153: S27-34. doi: 10.1038/sj.bjp.0707524

70. Cekic C, Day YJ, Sag D, Linden J. Myeloid expression of adenosine a2A receptor suppresses T and NK cell responses in the solid tumor microenvironment. Cancer Res 2014; 74: 7250-9. doi: 10.1158/0008-5472.CAN-133583

71. Liang $H$, Deng $L$, Hou $Y$, Meng $X$, Huang $X$, Rao E, et al. Host STINGdependent MDSC mobilization drives extrinsic radiation resistance. Nat Commun 2017; 8: 1736. doi: 10.1038/s41467-017-01566-5

72. Bakhoum SF, Ngo B, Laughney AM, Cavallo J-A, Murphy CJ, Ly P, et al. Chromosomal instability drives metastasis through a cytosolic DNA response. Nature 2018; 553: 467-72. doi: 10.1038/nature25432

73. Lemos H, Mohamed E, Huang L, Ou R, Pacholczyk G, Arbab AS, et al. STING promotes the growth of tumors characterized by low antigenicity via IDO activation. Cancer Res 2016; 76: 2076-81. doi: 10.1158/0008-5472.CAN15-1456

74. Monjazeb AM, Kent MS, Grossenbacher SK, Mall C, Zamora AE, Mirsoian A, et al. Blocking indolamine-2,3-dioxygenase rebound immune suppression boosts antitumor effects of radio-immunotherapy in murine models and spontaneous canine malignancies. Clin Cancer Res 2016; 22: 4328-40. doi: 10.1158/1078-0432.CCR-15-3026 
75. Jacquelot N, Yamazaki T, Roberti MP, Duong CPM, Andrews MC, Verlingue $\mathrm{L}$, et al. Sustained Type I interferon signaling as a mechanism of resistance to PD-1 blockade. Cell Res 2019; 29: 846-61. doi: 10.1038/s41422-019$0224-x$

76. Moeller BJ, Cao Y, Li CY, Dewhirst MW. Radiation activates HIF-1 to regulate vascular radiosensitivity in tumors. Cancer Cell 2004; 5: 429-41. doi: 10.1016/S1535-6108(04)00115-1

77. Corzo CA, Condamine T, Lu L, Cotter MJ, Youn J-I, Cheng P, et al. HIF-1 $\alpha$ regulates function and differentiation of myeloid-derived suppresso cells in the tumor microenvironment. J Exp Med 2010; 207: 2439-53. doi: 10.1084/jem.20100587

78. Suzuki H, Onishi H, Wada J, Yamasaki A, Tanaka H, Nakano K, et al. VEGFR2 is selectively expressed by FOXP3high CD4+ Treg. Eur J Immunol 2009; 40: 197-203. doi: 10.1002/eji.200939887

79. Gabrilovich D, Ishida T, Oyama T, Ran S, Kravtsov V, Nadaf S, et al. Vascular endothelial growth factor inhibits the development of dendritic cells and dramatically affects the differentiation of multiple hematopoietic lineages in vivo. Blood 1998; 92: 4150-66. doi: 10.1182/blood. v92.11.4150.423k45_4150_4166

80. Horikawa N, Abiko K, Matsumura N, Hamanishi J, Baba T, Yamaguchi K, et al. Expression of vascular endothelial growth factor in ovarian cancer inhibits tumor immunity through the accumulation of myeloid-derived suppressor cells. Clin Cancer Res 2017; 23: 587-99. doi: 10.1158/1078 0432.CCR-16-0387

81. National Comprehensive Cancer Network (NCCN). Head and Neck Cancers, Version 2.2020. (cited 2020 Jul 20). Available at: https://www.nccn.org

82. Ma Y, Adjemian S, Mattarollo SR, Yamazaki T, Aymeric L, Yang $H$, et al. Anticancer chemotherapy-induced intratumoral recruitment and differentiation of antigen-presenting cells. Immunity 2013; 38: 729-41. doi: 10.1016/j.immuni.2013.03.003

83. Crittenden MR, Zebertavage L, Kramer G, Bambina S, Friedman D, Troesch $V$, et al. Tumor cure by radiation therapy and checkpoint inhibitors depend on pre-existing immunity. Sci Rep 2018; 8: 1-15. doi: 10.1038/s41598-01825482-w

84. Markovsky E, Budhu S, Samstein RM, Li H, Russell J, Zhang Z, et al. An antitumor immune response is evoked by partial-volume single-dose radiation in 2 murine models. Int J Radiat Oncol 2019; 103: 697-708. doi: 10.1016/j. ijrobp.2018.10.009

85. Takeshima T, Chamoto K, Wakita D, Ohkuri T, Togashi $Y$, Shirato $H$, et al. Local radiation therapy inhibits tumor growth through the generation of tumor-specific CTL: its potentiation by combination with TH1 cell therapy. Cancer Res 2010; 70: 2697-706. doi: 10.1158/0008-5472.CAN-09-2982

86. Marciscano AE, Ghasemzadeh A, Nirschl TR, Theodros D, Kochel CM, Francica BJ, et al. Elective nodal irradiation attenuates the combinatorial efficacy of stereotactic radiation therapy and immunotherapy. Clin Cancer Res 2018; 24: 5058-71. doi: 10.1158/1078-0432.CCR-17-3427

87. Botticelli A, Mezi S, Pomati G, Sciattella P, Cerbelli B, Roberto M, et al. The impact of locoregional treatment on response to nivolumab in advanced platinum refractory head and neck cancer: The need trial. Vaccines 2020; 8: 191. doi: 10.3390/vaccines8020191

88. Zandberg DP, Ferris RL. Window studies in squamous cell carcinoma of the head and neck: values and limits. Curr Treat Options Oncol 2018; 19: 68. doi: 10.1007/s11864-018-0587-0

89. Leidner R, Bell RB, Young K, Curti B, Couey M, Patel A, et al. Abstract CT182: Neoadjuvant immuno-radiotherapy (NIRT) in head and neck cancer: Phase $\mathrm{l} / \mathrm{lb}$ study of combined PD-1/SBRT prior to surgical resection. [abstract]. In: Proceedings AACR Annual Meeting 2019; March 29-April 3, 2019; Atlanta, GA. Cancer Res 2019; 79(13 Suppl): CT182. doi: 10.1158/1538-7445. AM2019-CT182

90. Saâda-Bouzid E, Defaucheux C, Karabajakian A, Coloma VP, Servois V, Paoletti $X$, et al. Hyperprogression during anti-PD-1/PD-L1 therapy in patients with recurrent and/or metastatic head and neck squamous cell carcinoma. Ann Oncol 2017; 28: 1605-11. doi: 10.1093/annonc/mdx178

91. Bell RB, Leidner R, Young KH, Curti B, Couey M, Patel A, et al. Cohor expansion study of neoadjuant immunoradiotherapy in locoregionally advanced HPV+ and HPV- head and neck squamous cell carcinoma. Int J Radiat Oncol 2020; 106: 1225-6. doi: 10.1016/j.ijrobp.2020.02.013
92. Chin R. Stereotactic body radiation therapy and Durvalumab with or without Tremelimumab before surgery in treating participants with human papillomavirus positive oropharyngeal squamous cell cancer. (cited 2020 Jul 15). Available at: https://clinicaltrials.gov/ct2/show/NCT03618134

93. Economopoulou P, Kotsantis I, Psyrri A. The promise of immunotherapy in head and neck squamous cell carcinoma: combinatorial immunotherapy approaches. ESMO Open 2017; 1: e000122. doi: 10.1136/esmoopen-2016-000122

94. Barbari $C$, Fontaine $T$, Parajuli $P$, Lamichhane $N$, Jakubski $S$, Lamichhane $P$, et al. Immunotherapies and combination strategies for immuno-oncology. Int J Mol Sci 2020; 21: 5009. doi: 10.3390/ijms21145009

95. Diehl A, Yarchoan M, Hopkins A, Jaffee E, Grossman SA. Relationships between lymphocyte counts and treatment-related toxicities and clinical responses in patients with solid tumors treated with PD-1 checkpoint inhibitors. Oncotarget 2017; 8: 114268-80. doi: 10.18632/oncotarget.23217

96. Dovedi SJ, Adlard AL, Lipowska-Bhalla G, McKenna C, Jones S, Cheadle $E J$, et al. Acquired resistance to fractionated radiotherapy can be overcome by concurrent PD-L1 blockade. Cancer Res 2014; 74: 5458-68. doi: 10.1158/0008-5472.CAN-14-1258

97. Chen D, Patel RR, Verma V, Ramapriyan R, Barsoumian HB, Cortez MA, et al. Interaction between lymphopenia, radiotherapy technique, dosimetry, and survival outcomes in lung cancer patients receiving combined immunotherapy and radiotherapy. Radiother Oncol 2020 Avg 13; [Ahead of print]. doi: 10.1016/j.radonc.2020.05.051

98. Ho WJ, Yarchoan M, Hopkins A, Mehra R, Grossman S, Kang H. Association between pretreatment lymphocyte count and response to PD1 inhibitors in head and neck squamous cell carcinomas. J Immunother Cancer 2018; 6: 84. doi: 10.1186/s40425-018-0395-x

99. Kaanders JHAM, van den Bosch S, Dijkema T, Al-Mamgani A, Raaijmakers $\mathrm{CPJ}$, Vogel $\mathrm{W} \mathrm{V}$. Advances in cancer imaging require renewed radiotherapy dose and target volume concepts. Radiother Oncol 2020; 148: 140-2. doi: 10.1016/j.radonc.2020.04.016

100. Grapin M, Richard C, Limagne E, Boidot R, Morgand V, Bertaut A, et al. Optimized fractionated radiotherapy with anti-PD-L1 and anti-TIGIT: a promising new combination. J Immunother Cancer 2019; 7: 1-12. doi: $10.1186 / s 40425-019-0634-9$

101. Filatenkov A, Baker J, Mueller AMS, Kenkel J, Ahn GO, Dutt S, et al. Ablative tumor radiation can change the tumor immune cell microenvironment to induce durable complete remissions. Clin Cancer Res 2015; 21: 3727-39. doi: 10.1158/1078-0432.CCR-14-2824

102. Bernier J, Domenge C, Ozsahin M, Matuszewska K, Lefèbvre J-L, Greiner $\mathrm{RH}$, et al. Postoperative irradiation with or without concomitant chemotherapy for locally advanced head and neck cancer. N Engl J Med 2004; 350: 1945-52 doi: 10.1056/NEIMoa032641

103. Forastiere AA, Goepfert H, Maor M, Pajak TF, Weber R, Morrison W, et al. Concurrent chemotherapy and radiotherapy for organ preservation in advanced laryngeal cancer. N Engl J Med 2003; 349: 2091-8. doi: 10.1056/ NEJMoa031317

104. Yoon S-Y, Han JJ, Baek SK, Kim HJ, Maeng CH. Pembrolizumab-induced severe oral mucositis in a patient with squamous cell carcinoma of the lung: a case study. Lung Cancer 2020; 147: 21-5. doi: 10.1016/j.lungcan.2020.06.033

105. García-Foncillas J, Sunakawa Y, Aderka D, Wainberg Z, Ronga P, Witzler $\mathrm{P}$, et al. Distinguishing features of Cetuximab and Panitumumab in colorectal cancer and other solid tumors. Front Oncol 2019; 9: 849. doi:10.3389/ fonc.2019.00849

106. Ferris RL, Lenz H-J, Trotta AM, García-Foncillas J, Schulten J, Audhuy F, et al. Rationale for combination of therapeutic antibodies targeting tumor cells and immune checkpoint receptors: harnessing innate and adaptive immunity through IgG1 isotype immune effector stimulation. Cancer Treat Rev 2018; 63: 48-60. doi: 10.1016/j.ctrv.2017.11.008

107. Sacco AG, Chen R, Ghosh D, Worden F, Wong DJ, Adkins D, et al. An openlabel, non-randomized, multi-arm, phase II trial evaluating pembrolizumab combined with cetuximab in patients (pts) with recurrent/metastatic (R/M) head and neck squamous cell carcinoma (HNSCC): updated results of cohort 1 analysis. Int J Radiat Oncol 2020; 106: 1121-2. doi: 10.1016/j. ijrobp.2019.11.376 
108. Lin Y-C, Uen W-C, Hao S-P, Hsiao C-Y, Lai H-C. Triple combination treatment of cetuximab, chemotherapy, and anti-PD1 check-point inhibitor for recurrent and/or metastatic head and neck squamous cell carcinoma: a single institute experience. J Clin Oncol 2018; 36: e18001. doi: 10.1200/ JCO.2018.36.15_suppl.e18001

109. EMD Serono and Pfizer provide update on phase III JAVELIN Head and Neck 100 Study. (cited 2020 Jul 15). Available at: https://www.pfizer.com/news/ press-release/press-release-detail/emd_serono_and_pfizer_provide_update_on_phase_iii_javelin_head_and_neck_100_study

110. Yu Y, Lee NY. JAVELIN Head and Neck 100: a Phase III trial of avelumab and chemoradiation for locally advanced head and neck cancer. Futur Oncol 2019; 15: 687-94. doi: 10.2217/fon-2018-0405

111. Tao Y, Auperin A, Sun XS, Sire C, Martin L, Bera G, et al. Avelumabcetuximab-radiotherapy (RT) versus standards of care (SoC) in locally advanced squamous cell carcinoma of the head and neck (SCCHN): safety phase of the randomized trial GORTEC 2017-01 (REACH). J Clin Oncol 2018; 36: 6076. doi: 10.1200/jco.2018.36.15_suppl.6076

112. Tao Y, Auperin A, Sun XS, Sire C, Martin L, Bera G, et al. Avelumabcetuximab-radiotherapy versus standards of care in locally advanced squamous cell carcinoma of the head and neck: safety phase of the randomized phase III trial GORTEC 2017-01 REACH. (cited 2020 Jul 15). Available at: https://www.gortec.net/images/publi/ESMO2019_REACH_ POSTER_Discussion.pdf

113. Mell LK, Torres-Saavedra PA, Wong SJ, Chang S, Kish JA, Minn A, et al. Safety of radiotherapy with concurrent and adjuvant MEDI4736 (durvalumab) in patients with locoregionally advanced head and neck cancer with a contraindication to cisplatin: NRG-HN004. J Clin Oncol 2019; 37: 6065. doi: 10.1200/JCO.2019.37.15 suppl.6065

114. Sun XS, Sire C, Tao Y, Martin L, Alfonsi M, Prevost JB, et al. A phase I randomized trial of pembrolizumab versus cetuximab, concomitant with radiotherapy (RT) in locally advanced (LA) squamous cell carcinoma of the head and neck (SCCHN): first results of the GORTEC 2015-01 "PembroRad" trial. J Clin Oncol 2018; 36: 6018. doi: 10.1200/jco.2018.36.15_suppl.6018

115. Klinghammer KF, Gauler TC, Stromberger C, Kofla G, de Wit M, Gollrad J, et al. DURTRERAD: a phase II open-label study evaluating feasibility and efficacy of durvalumab (D) and durvalumab and tremelimumab (DT) in combination with radiotherapy (RT) in non-resectable locally advanced HPV-negative HNSCC - results of the preplanned feasibi. J Clin Oncol 2020; 38: 6574 . doi: $10.1200 / J C O .2020 .38 .15$ suppl.6574

116. Weiss J, Sheth S, Deal AM, Grilley Olson JE, Patel S, Hackman TG, et al. Concurrent definitive immunoradiotherapy for patients with stage III-IV head and neck cancer and cisplatin contraindication. Clin Cancer Res 2020; 26: 4260-7. doi: 10.1158/1078-0432.CCR-20-0230

117. Powell SF, Gold KA, Gitau MM, Sumey CJ, Lohr MM, McGraw SC, et al. Safety and efficacy of pembrolizumab with chemoradiotherapy in locally advanced head and neck squamous cell carcinoma: a phase IB study. J Clin Oncol 2020; 38: 2427-37. doi: 10.1200/JCO.19.03156

118. Gillison M, Ferris RL, Zhang Q, Colevas AD, Mell LK, Kirsch C, et al. Safety evaluation of nivolumab concomitant with platinum-based chemoradiation therapy for intermediate and high-risk local-regionally advanced head and neck squamous cell carcinoma: RTOG foundation 3504. Int J Radiat Oncol 2018; 100: 1307-8. doi: 10.1016/j.jijrobp.2017.12.022

119. Ferris RL, Gillison ML, Harris J, Colevas AD, Mell LK, Kong C, et al. Safety evaluation of nivolumab (Nivo) concomitant with cetuximab-radiotherapy for intermediate (IR) and high-risk (HR) local-regionally advanced head and neck squamous cell carcinoma (HNSCC): RTOG 3504. J Clin Oncol 2018; 36: 6010. doi: $10.1200 / J C O .2018 .36 .15$ suppl.6010

120. Gillison ML, Ferris RL, Harris J, Colevas AD, Mell LK, Kong C, et al. Safety and disease control achieved with the addition of nivolumab (Nivo) to chemoradiotherapy (CRT) for intermediate (IR) and high-risk (HR) localregionally advanced head and neck squamous cell carcinoma (HNSCC): RTOG Foundation 3504. J Clin Oncol 2019; 37: 6073. doi: 10.1200/ jco.2019.37.15_suppl.6073

121. Johnson JM, Bar Ad V, Lorber E, Poller D, Luginbuhl A, Curry JM, et al. Safety of nivolumab and ipilimumab in combination with radiotherapy in patients with locally advanced squamous cell carcinoma of the head and neck (LA SCCHN). J Clin Oncol 2019; 37: 6070. doi: 10.1200/JCO.2019.37.15_suppl.6070
122. Elbers JBW, Al-Mamgani A, Tesseslaar MET, van den Brekel MWM, Lange $\mathrm{CAH}$, van der Wal JE, et al. Immuno-radiotherapy with cetuximab and avelumab for advanced stage head and neck squamous cell carcinoma: results from a phase-I trial. Radiother Oncol 2020; 142: 79-84. doi: 10.1016/j. radonc.2019.08.007

123. Hecht $M$, Gostian A-O, Eckstein M, Rutzner $\mathrm{S}$, von der Grün J, Illmer T, et al. Single cycle induction treatment with cisplatin/docetaxel plus durvalumab/ tremelimumab in stage III-IVB head and neck squamous cell cancer (CheckRad-CD8 trial). Ann Oncol 2019; 30: v456-7. doi: 10.1093/annonc/ $\mathrm{mdz} 252.016$

124. Machiels J-P, Tao Y, Burtness B, Tahara M, Licitra L, Rischin D, et al. Pembrolizumab given concomitantly with chemoradiation and as maintenance therapy for locally advanced head and neck squamous cell carcinoma: KEYNOTE-412. Futur Oncol 2020; 16: 1235-43. doi: 10.2217/ fon-2020-0184

125. Nivolumab or nivolumab plus cisplatin, in combination with radiotherapy in patients with cisplatin-ineligible or eligible locally advanced squamous cell head and neck cancer. (cited 2020 Jul 15). Available at: https://clinicaltrials.gov/ct2/show/NCT03349710

126. Yom SS. De-intensified radiation therapy with chemotherapy (cisplatin) or immunotherapy (nivolumab) in treating patients with early-stage, HPVpositive, non-smoking associated oropharyngeal cancer. (cited $2020 \mathrm{Jul}$ 15). Available at: https://clinicaltrials.gov/ct2/show/NCT03952585

127. Ferris RL. HPV-16 Vaccination and pembrolizumab plus cisplatin for "intermediate risk" HPV-16-associated head and neck squamous cell carcinoma. (cited $2020 \mathrm{Jul}$ 15). Available at: https://clinicaltrials.gov/ct2/show/ NCT04369937

128. Massarelli E, William W, Johnson F, Kies M, Ferrarotto R, Guo M, et al. Combining immune checkpoint blockade and tumor-specific vaccine for patients with incurable human papillomavirus 16 -related cancer. JAMA Oncol 2019; 5: 67. doi: 10.1001/jamaoncol.2018.4051

129. Trial evaluating the tolerance and safety of durvalumab - RT combination for treatment in SCCHN (REWRITe). (cited 2020 Jul 15). Available at: https://clinicaltrials.gov/ct2/show/NCT03726775

130. Clump D. Pembrolizumab in combination with cisplatin and intensity modulated radiotherapy (IMRT) in head and neck cancer. (cited $2020 \mathrm{Ju}$ 15). Available at: https://clinicaltrials.gov/ct2/show/NCT02777385

131. Takiar V. A study of chemoradiation plus pembrolizumab for locally advanced laryngeal squamous cell carcinoma. (cited $2020 \mathrm{Jul}$ 15). Available at: https://clinicaltrials.gov/ct2/show/NCT02759575

132. El-Sherify MS. Concomitant immune check point inhibitor with radiochemotherapy in head and neck cancer. (cited $2020 \mathrm{Jul}$ 15). Available at: https://clinicaltrials.gov/ct2/show/NCT03532737

133. Mell L. Chemoradiation vs immunotherapy and radiation for head and neck cancer. (cited $2020 \mathrm{Jul}$ 15). Available at: https://clinicaltrials.gov/ct2/ show/NCT03383094

134. Harrington K. Pembrolizumab combined with chemoradiotherapy in squamous cell carcinoma of the head and neck (PEACH). (cited 2020 Jul 15). Available at: https://clinicaltrials.gov/ct2/show/NCT02819752

135. Haddad R. Induction TPN followed by nivolumab with radiation in locoregionally advanced laryngeal and hypopharyngeal cancer. (cited $2020 \mathrm{Jul}$ 15). Available at: https://clinicaltrials.gov/ct2/show/NCT03894891

136. Mierzwa M. Radiotherapy, carboplatin/paclitaxel and nivolumab for high risk HPV-related head and neck cancer. (cited 2020 Jul 15). Available at: https://clinicaltrials.gov/ct2/show/NCT03829722

137. Gillison ML. Ipilimumab, nivolumab, and radiation therapy in treating patients with HPV positive advanced oropharyngeal squamous cell carcinoma. (cited $2020 \mathrm{Jul}$ 15). Available at: https://clinicaltrials.gov/ct2/show/ NCT03799445

138. Tao Y, Auperin A, Sun XS, Sire C, Martin L, Bera G, et al. Avelumabcetuximab-radiotherapy versus standards of care in locally advanced squamous cell carcinoma of the head and neck: safety phase of the randomized phase III trial GORTEC 2017-01 REACH. (cited 2020 Jul 15). Available at: https://gortec.net/images/publi/ESMO2019_REACH_POSTER_Discussion. pdf 
139. Bonomo P, Desideri I, Loi M, Mangoni M, Sottili M, Marrazzo L, et al. Anti PD-L1 durvalumab combined with cetuximab and radiotherapy in locally advanced squamous cell carcinoma of the head and neck: a phase I/II study (DUCRO). Clin Transl Radiat Oncol 2018; 9: 42-7. doi: 10.1016/j. ctro.2018.01.005

140. Cisplatin or immunotgerapy in association with definitive radiotherapy in HPV-related oropharyngEal squamous cell carcinoma: a randomized phase II trial. (CITHARE). (cited 2020 Jul 15). Available at: https://clinicaltrials.gov/ ct2/show/NCT03623646

141. Li Y. A study of concomitant camrelizumab with chemoradiation for locally advanced head and neck cancer. (cited 2020 Jul 15). Available at: https:// clinicaltrials.gov/ct2/show/NCT04405154

142. Wise-Draper TM, Old MO, Worden FP, O'Brien PE, Cohen EEW, Dunlap $\mathrm{N}$, et al. Phase II multi-site investigation of neoadjuvant pembrolizumab and adjuvant concurrent radiation and pembrolizumab with or without cisplatin in resected head and neck squamous cell carcinoma. J Clin Oncol 2018; 36: 6017. doi: 10.1200/JCO.2018.36.15 suppl.6017

143. Bauman JE, Harris J, Uppaluri R, Yao M, Ferris RL, Chen J, et al. NRG-HN003: Phase I and expansion cohort study of adjuvant cisplatin, intensity-modulated radiation therapy (IMRT), and MK-3475 (pembrolizumab) in high-risk head and neck squamous cell carcinoma (HNSCC). J Clin Oncol 2019; 37: 6023. doi: 10.1200/JCO.2019.37.15_suppl.6023

144. Uppaluri R, Lee NY, Westra W, Cohen EEW, Haddad RI, Temam S, et al. KEYNOTE-689: Phase 3 study of adjuvant and neoadjuvant pembrolizumab combined with standard of care (SOC) in patients with resectable, locally advanced head and neck squamous cell carcinoma. J Clin Oncol 2019; 37: TPS6090. doi: 10.1200/JCO.2019.37.15 suppl.TPS6090

145. Uppaluri $\mathrm{R}$, Lee NY, Westra W, Cohen EEW, Haddad $\mathrm{Rl}$, Temam $\mathrm{S}$, et al. KEYNOTE-689: phase 3 study of neoadjuvant and adjuvant pembrolizumab combined with standard of care in patients with resectable, locally advanced head and neck squamous cell carcinoma. (cited $2020 \mathrm{Jul}$ 15). Available at: http://uppalurilab.dana-farber.org/uploads/1/2/9/7/129766176/uppaluri_kn689_asco_2019_poster_presented.pdf

146. A trial evaluating the addition of nivolumab to cisplatin-RT for treatment of cancers of the head and neck (NIVOPOSTOP). (cited $2020 \mathrm{Jul} 15$ ). Available at: https://clinicaltrials.gov/ct2/show/NCT03576417

147. Maintenance immune check-point inhibitor following post-operative chemo-radiation in subjects with HPV-negative HNSCC (ADHERE). (cited 2020 Jul 15). Available at: https://clinicaltrials.gov/ct2/show/NCT03673735

148. Cooper JS, Pajak TF, Forastiere AA, Jacobs J, Campbell BH, Saxman SB, et al. Postoperative concurrent radiotherapy and chemotherapy for high-risk squamous-cell carcinoma of the head and neck. N Engl J Med 2004; 350: 1937-44. doi: 10.1056/NEJMoa032646

149. Dietz A. Postoperative aRCH with cisplatin versus $\mathrm{aRCH}$ with cisplatin and pembrolizumab in locally advanced head and neck squamous cell carcinoma. (cited $2020 \mathrm{Jul}$ 14). Available at: https://clinicaltrials.gov/ct2/show/ NCT03480672

150. Ferris R. Adjuvant de-escalated radiation + adjuvant nivolumab for intermediate-high risk P16+ oropharynx cancer. (cited 2020 Jul 15). Available at: https://clinicaltrials.gov/ct2/show/NCT03715946

151. Weiss J. Durvalumab with radiotherapy for adjuvant treatment of intermediate risk SCCHN. (cited 2020 Jul 16). Available at: https://clinicaltrials.gov/ ct2/show/NCT03529422

152. Antonia SJ, Villegas A, Daniel D, Vicente D, Murakami S, Hui R, et al. Overall survival with durvalumab after chemoradiotherapy in stage III NSCLC. N Engl J Med 2018; 379: 2342-50. doi: 10.1056/NEJMoa1809697

153. Weber JS, Mandalà M, Del Vecchio M, Gogas H, Arance AM, Cowey CL, et al. Adjuvant therapy with nivolumab (NIVO) versus ipilimumab (IPI) after complete resection of stage III/IV melanoma: updated results from a phase III trial (CheckMate 238). J Clin Oncol 2018; 36: 9502. doi: 10.1200/ JCO.2018.36.15 suppl.9502

154. Eggermont AMM, Chiarion-Sileni V, Grob J-J, Dummer R, Wolchok JD, Schmidt $\mathrm{H}$, et al. Adjuvant ipilimumab versus placebo after complete resection of stage III melanoma: long-term follow-up results of the European Organisation for Research and Treatment of Cancer 18071 double-blind phase 3 randomised trial. Eur J Cancer 2019; 119: 1-10. doi: 10.1016/j. ejca.2019.07.001
155. Steuer CE, Behera M, Ernani V, Higgins KA, Saba NF, Shin DM, et al. Comparison of concurrent use of thoracic radiation with either carboplatin-paclitaxel or cisplatin-etoposide for patients with stage III nonsmall-cell lung cancer. JAMA Oncol 2017; 3: 1120. doi: 10.1001/jamaoncol.2016.4280

156. Duprez F, Berwouts D, De Neve W, Bonte K, Boterberg T, Deron P, et al Distant metastases in head and neck cancer. Head Neck 2017; 39: 1733-43. doi: $10.1002 /$ hed. 24687

157. Wang H, Mustafa A, Liu S, Liu J, Lv D, Yang H, et al. Immune checkpoint inhibitor toxicity in head and neck cancer: from identification to management. Front Pharmacol 2019; 10: doi: 10.3389/fphar.2019.01254

158. Santana-Davila R, Rodriguez CP. Immunotherapy for head and neck cancer in the era of exponentially increasing health care expenditure. Oncologist 2018; 23: 147-9. doi: 10.1634/theoncologist.2017-0527

159. Gavrielatou N, Doumas S, Economopoulou P, Foukas PG, Psyrri A. Biomarkers for immunotherapy response in head and neck cancer. Cancer Treat Rev 2020; 84: 101977. doi: 10.1016/j.ctrv.2020.101977 